Tetrahedron report number 996

\title{
Syntheses, transformations and applications of aminonaphthol derivatives prepared via modified Mannich reactions
}

\author{
István Szatmári, Ferenc Fülöp* \\ Institute of Pharmaceutical Chemistry and Stereochemistry Research Group, Hungarian Academy of Sciences, University of Szeged, H-6720 Szeged, Eötvös u. 6, Hungary
}

\section{A R T I C L E I N F O}

\section{Article history:}

Received 8 November 2012

Available online 23 November 2012

\section{Keywords:}

Mannich reaction

Aminonaphthol

Aminoquinolinol

Aminoisoquinolinol

Isoquinolinonaphthol

Isoquinolinoquinolinol

Isoquinolinoisoquinolinol

Naphthoxazine

Ring-chain tautomerism

Enantioselective transformations

\section{Contents}

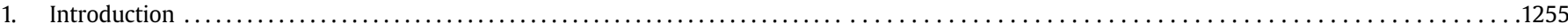

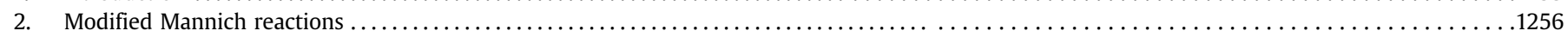

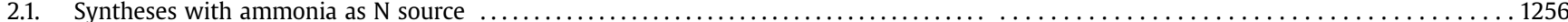

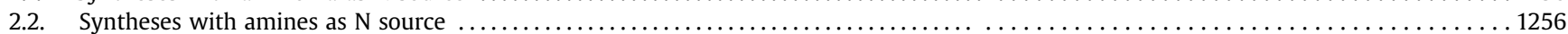

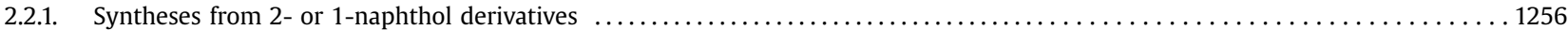

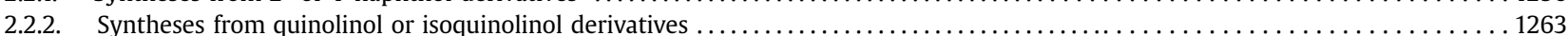

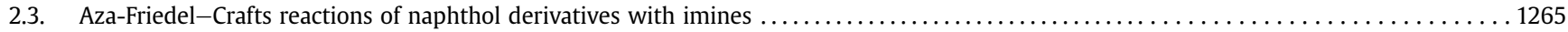

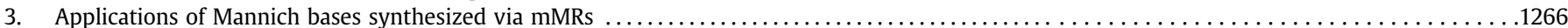

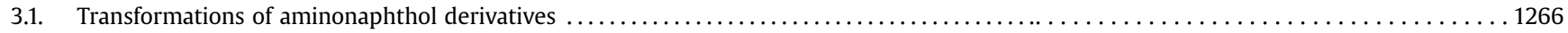

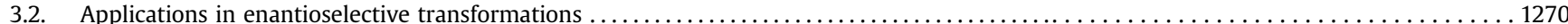

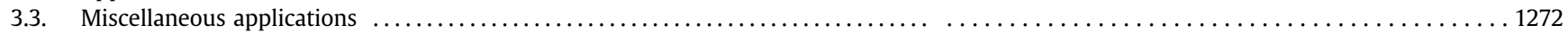

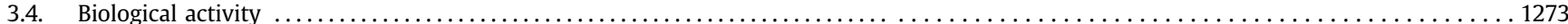

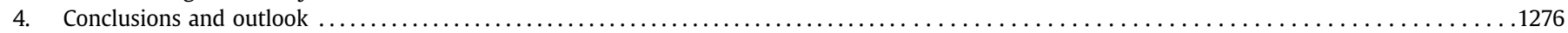

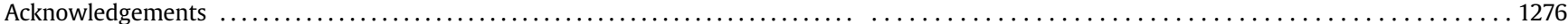

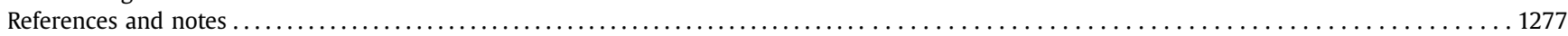

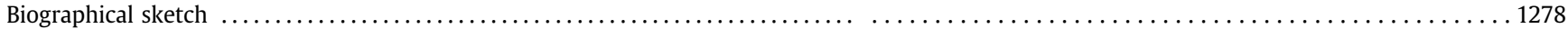

\section{Introduction}

The Mannich reaction is one of the most frequently applied multicomponent reactions in organic chemistry. ${ }^{1,2}$ In the original form of the reaction, the Mannich product is formed through the reaction of a $\mathrm{C}-\mathrm{H}$ acid, formaldehyde and a secondary amine. 
A special alteration is the three-component modified Mannich reaction (mMR), in which formaldehyde is replaced by an aromatic aldehyde, the secondary amine by ammonia, and the $\mathrm{C}-\mathrm{H}$ acid by an electron-rich aromatic compound such as 1- or 2-naphthol, quinolinol or isoquinolinol. Based on this, it can be interpreted as a formal Mannich reaction. Starting from ammonia, benzaldehyde, and 2-naphthol in this mMR, 100 years ago, Mario Betti reported the straightforward synthesis of 1,3-diphenylnaphthoxazine in methanol. Acidic hydrolysis of the ring compound produced led to 1-aminobenzyl-2-naphthol. The aminonaphthol product became known in the literature as a Betti base, and the protocol as the Betti reaction. ${ }^{3-5}$ This reaction has subsequently been extended by using different $N$ sources, the order and character of which (ammonia, amine or amide) greatly determine the reaction conditions and the method of isolation of the Mannich product. ${ }^{6}$ On the other hand, the use of non-racemic amines has opened up a new area of application of enantiopure aminonaphthols as chiral catalysts in enantioselective transformations. ${ }^{6}$

The syntheses of a wide-ranging library of racemic and nonracemic Betti base derivatives were recently reviewed, ${ }^{7}$ with special attention to their use as versatile $N, O$ and $N, P$ ligands for organometallic processes, and to the possibilities of their application as building blocks. With regard to the synthetic potential of this reaction, we consider that some additional aspects should now be surveyed. One of these is the application of amides or their derivatives as $N$ sources in mMRs. ${ }^{8-10}$ This can be interpreted as a further extension of this reaction, with a large number of publications. On the other hand, in consequence of the relatively low reactivity of the $\mathrm{N}$-containing naphthol analogues, there are comparatively few examples of their transformations in mMRs. ${ }^{11-13}$ Some relevant publications did appear earlier, but it seems that their promising biological activity has led to the chemistry of these compounds again becoming a hot topic. ${ }^{14-16}$

\section{Modified Mannich reactions}

This section will deal with the different variants of the mMR. The subsections are divided according to the amine source applied. Since the possible variations of the aldehyde component greatly increase the diversity of the topic, these modifications will be treated in the following sections and will not be discussed separately.

\subsection{Syntheses with ammonia as $\mathrm{N}$ source}

A new approach was published by the present authors, who successfully applied ammonium acetate and formate (as solid ammonia sources that are greener than methanolic ammonia solution) to prepare 3a-d (Scheme 1) and $\mathbf{6 a}-\mathbf{h}$ (Scheme 2). The reaction mixtures contained 2-naphthol (1), 1-naphthol (4a) or their $\mathrm{N}$-containing analogues $(\mathbf{4 b}, \mathbf{c})$, an aromatic, heteroaromatic or aliphatic aldehyde and a solid ammonia source. Use of ammonium acetate or formate led to $\mathbf{2} \mathbf{a}-\mathbf{d}$ or $\mathbf{5 a}-\mathbf{h}$, but their isolation required an aqueous work-up, which meant that the rapidity and one-pot handling of the reaction were lost. Similar results were obtained with several equivalents of ammonium carbamate $\left(\mathrm{NH}_{4} \mathrm{OOCNH}{ }_{2}\right)$, which yielded $\mathbf{3 a}-\mathbf{d}$ or $\mathbf{6 a}-\mathbf{h}^{17}$

Through the use of salicylaldehyde, functionalized aminonaphthol analogue $3 \mathbf{e}$ was prepared. The reaction was achieved through acidic hydrolysis of intermediate $\mathbf{2 e}$ with TFA. ${ }^{18}$

Turgut et al. extended the series of aminonaphthols by using different aromatic aldehydes, but it should be noted that hydrolysis of the intermediate naphthoxazines $(\mathbf{2} \mathbf{b}, \mathbf{f}-\mathbf{l})$ was performed only in some cases (3f-h, Scheme 1$){ }^{19}$

On the application of 1- or 2-naphthaldehyde in the mMR, aminonaphthols $\mathbf{3 m}$ and $\mathbf{3 n}$ were prepared by the acidic hydrolysis of the intermediates $\mathbf{2 m}$ and $\mathbf{2 n}$ (Scheme 1 ). ${ }^{20}$ The reaction was extended to 1 -naphthol, yielding $\mathbf{6 i}$ and $\mathbf{6 j}$ via $\mathbf{5 i}$ and $\mathbf{5 j}$ (Scheme 2 ). ${ }^{20}$

The present authors first applied aliphatic aldehydes in the mMR to obtain 3d,o-r. In those experiments, naphthoxazines $\mathbf{2 d}, \mathbf{0}-\mathbf{r}$ were formed by the condensation of 2-naphthol and the corresponding aliphatic aldehyde in the presence of methanolic ammonia at $60{ }^{\circ} \mathrm{C}$. The acidic hydrolysis of $\mathbf{2 d , 0}-\mathbf{r}$ led to the desired aminonaphthols $\mathbf{3 d}, \mathbf{0}-\mathbf{r}$ in low yields in a two-step process. The overall yield was improved considerably when the residue of 2d,o-r was directly hydrolysed with hydrochloric acid (Scheme 1). ${ }^{21}$

An improved method for the enantioseparation of racemic 3a involved the in situ reaction of $\mathbf{2 a}$ with $\mathrm{L}-(+)$-tartaric acid in a ratio of $1: 1$. The products of this reaction were $(S)$-3a tartrate, the acetal of benzaldehyde and tartaric acid, and (+)-2a, which were easily separated by crystallization (Scheme 1$)^{22}$

Harrison et al. recently reported the syntheses of 6-bromosubstituted aminonaphthol derivatives $(\mathbf{9 a}-\mathbf{n})$ from 6-bromo-2naphthol (7), methanolic ammonia and the corresponding aromatic aldehyde. The naphthoxazine intermediates $8 \mathbf{a}-\mathbf{n}$ were hydrolysed with hydrochloric acid to yield the desired aminonaphthol derivatives $\mathbf{9 a}-\mathbf{n}$ (Scheme 3 ). ${ }^{23}$

The one-pot procedure reported by Foroughifar et al. for the preparation of 4,9-dihydroxy-1,3-diaryl-2,3-dihydro-2-azaphenalenes 11a-m from aromatic aldehydes, 2,7-naphthalenediol (10) and ammonia or two ammonium salts was optimized through the use of ammonium hydrogenphosphate in a mixture of ethanol-water under reflux conditions (Scheme 4). ${ }^{24}$

\subsection{Syntheses with amines as $\mathbf{N}$ source}

2.2.1. Syntheses from 2- or 1-naphthol derivatives. A simple microwave-assisted one-pot synthesis of $\mathbf{1 2}$ or $\mathbf{1 3}$ (Scheme 5) from 2-naphthol, the corresponding aldehydes and amines was carried out by Jha et al. under solvent-free conditions in the presence of $p$-TSA. ${ }^{25}$ The yields were improved by the application of a non-ionic surfactant (Triton X-100) in water, ${ }^{26}$ or by using basic nanocrystalline $\mathrm{MgO}$ as catalyst in an aqueous medium. ${ }^{27}$

1-((2-Hydroxynaphthalen-1-yl)arylmethyl)piperidin-4-ol derivatives $(\mathbf{1 4 a}-\mathbf{j})$ as novel selective oestrogen receptor modulators

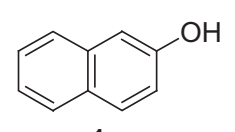

1

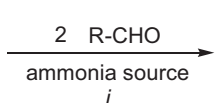

i

$\mathrm{R}=\mathrm{P}$

Ph: a; 2-thienyl: b; 3-thienyl: c; i-Pr: d; 2-OH-C ${ }_{6} \mathrm{H}_{4}$ : e; 3-OPh- $\mathrm{C}_{6} \mathrm{H}_{4}: \mathbf{f} ; 3$, 4-di-OMe- $\mathrm{C}_{6} \mathrm{H}_{3}: \mathbf{g}$

3,4,5-tri-OMe- ${ }_{6} \mathrm{H}_{2}$ : h; 3-OH-C ${ }_{6} \mathrm{H}_{4}$ : i; 3,4-di-Me- ${ }_{6} \mathrm{H}_{3}: \mathbf{j} ; 2-\mathrm{OH}, 5-\mathrm{Br}_{-} \mathrm{C}_{6} \mathrm{H}_{3}$ : k; 2-py: I;

1-Nph: m; 2-Nph: n; Me: o; Et: p; Pr: q; $t$-Bu: $\mathbf{r}$ 


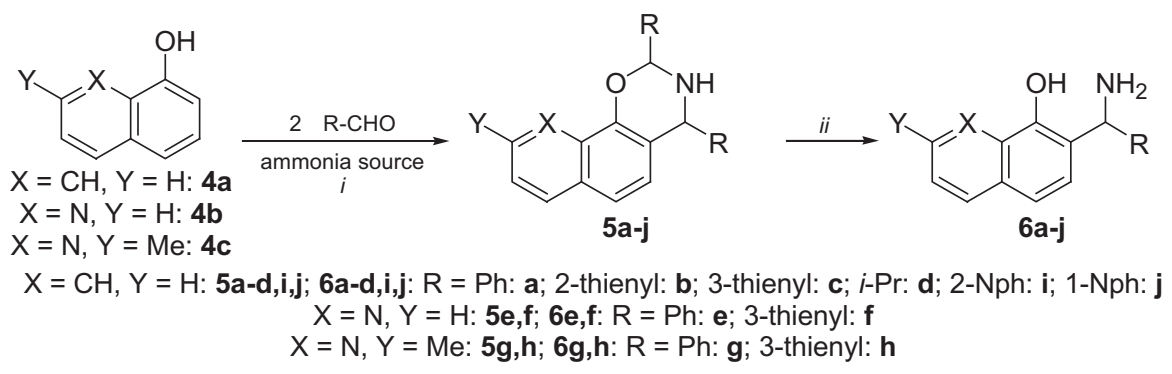

Scheme 2. Syntheses of 2-aminomethyl-1-naphthol or 7-aminomethyl-8-quinolinol derivatives $\mathbf{6}$.

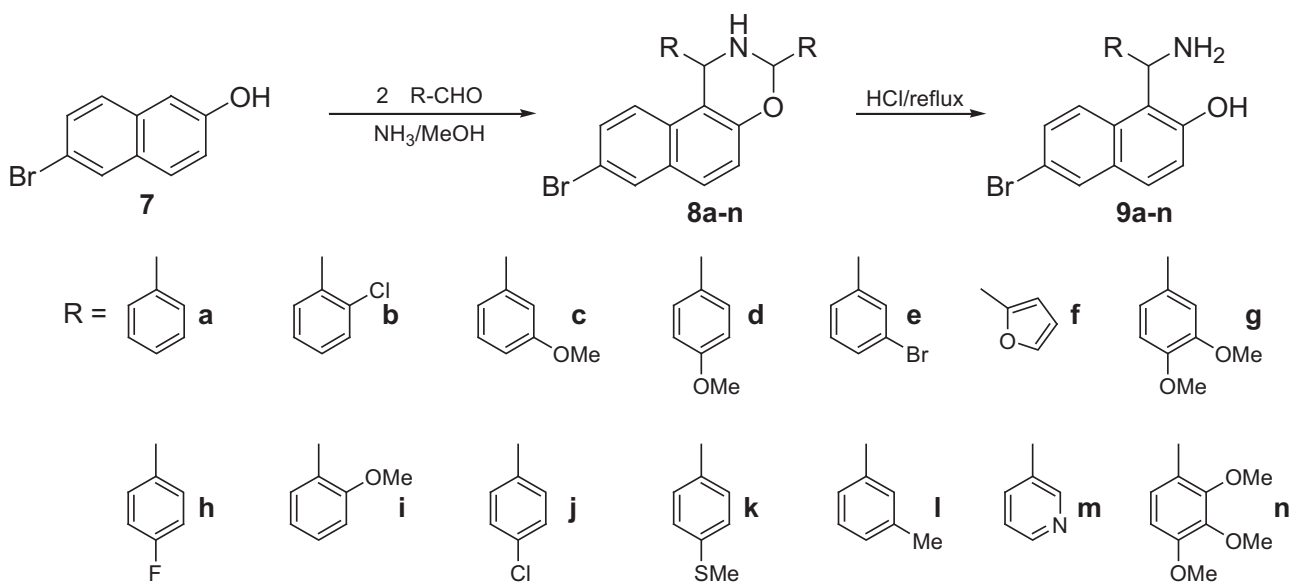

Scheme 3. Syntheses of 6-bromo-substituted aminonaphthol derivatives $\mathbf{9}$.

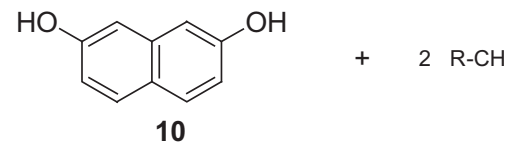<smiles>[R]=Cc1ccccc1</smiles><smiles>Cc1ccc(C)cc1</smiles><smiles>Cc1ccc(Cl)cc1</smiles><smiles>Cc1ccc(Br)cc1</smiles><smiles>Cc1cccc(Br)c1</smiles><smiles>Cc1ccc(F)cc1</smiles><smiles>Cc1cccc([N+](=O)[O-])c1</smiles><smiles>Cc1ccc(O)cc1</smiles>

Scheme 4. Symmetric aminoalkylation of 2,7-naphthalenediol.

were designed and synthesized by Jha et al. via the mMR protocol from 2-naphthol (1), 4-piperidinol and 10 different aromatic aldehydes. ${ }^{28}$ With the aim of a better biological effect, the structure of 14 was extended with different dialkylaminoethoxy substituents at position-4 of the aryl group (15a-f, Scheme 6) ${ }^{29}$

The syntheses of naphth[2,1-e][1,3]oxazines $\mathbf{1 6}$ or naphth[1,2-e] [1,3]oxazines 17 from amine, 2 equiv of formalin and 1- or 2 naphthol with water as solvent were described by Nath et al. ${ }^{30}$ The same reaction was achieved by Shingare et al. with $\mathrm{KAl}(-$ $\left.\mathrm{SO}_{4}\right)_{2} \cdot 12 \mathrm{H}_{2} \mathrm{O}$ as a reusable, non-toxic inexpensive catalyst. It should be mentioned that, in this case, water was applied as solvent (Scheme 7). ${ }^{31}$
Technically, one of the most important areas of the chemistry of mMRs is the synthesis of enantiopure aminonaphthol derivatives and their application as chiral ligands. The syntheses and applications of these non-racemic aminonaphthols up to 2004 were reviewed earlier. ${ }^{6}$ In spite of the excellent chiral induction of those aminonaphthols, only a few publications have subsequently appeared in this field. For instance, the insertion of a bulkier aromatic ring (e.g., naphthyl) at different positions proved successful. From 2-naphthol (1), 1-naphthaldehyde (20a) and $(R)-(+)-\alpha-$ methylbenzylamine (19a) or $(R)-(+)-N$-methyl- $\alpha$-methylbenzylamine (19b), 21a and 21b, respectively (Table 1 ), have been prepared. $^{32}$ The bulkier naphthyl ring was inserted through the amine 
<smiles>[R]NC([R])c1c(O)ccc2ccccc12</smiles>

12

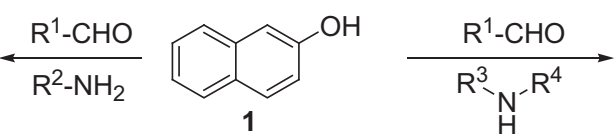

1<smiles>[R]C(c1c(O)ccc2ccccc12)N([R])C</smiles>

13

$\mathrm{R}^{1}=\mathrm{H} ; 2-\mathrm{NO}_{2}-\mathrm{C}_{6} \mathrm{H}_{4} ; 3-\mathrm{NO}_{2}-\mathrm{C}_{6} \mathrm{H}_{4} ; 4-\mathrm{NO}_{2}-\mathrm{C}_{6} \mathrm{H}_{4} ; 4-\mathrm{F}-\mathrm{C}_{6} \mathrm{H}_{4} ; 4-\mathrm{Cl}_{-} \mathrm{C}_{6} \mathrm{H}_{4} ; 3-\mathrm{Br}-\mathrm{C}_{6} \mathrm{H}_{4} ; 4-\mathrm{CN}-\mathrm{C}_{6} \mathrm{H}_{4} ; \mathrm{C}_{6} \mathrm{H}_{5} ; 4-\mathrm{Me}_{6} \mathrm{C}_{6} \mathrm{H}_{4}$; 2-OMe- $\mathrm{C}_{6} \mathrm{H}_{4} ; 4-\mathrm{OMe}_{2} \mathrm{C}_{6} \mathrm{H}_{4} ; 3,4-$ di-OMe- $\mathrm{C}_{6} \mathrm{H}_{3} ; 3,4,5$-tri-OMe- $\mathrm{C}_{6} \mathrm{H}_{2} ; 4-\mathrm{NMe}_{2}-\mathrm{C}_{6} \mathrm{H}_{4} ; 4$-py; 2-furyl

$$
\mathrm{R}^{2}=\mathrm{Bu},-\mathrm{CH}_{2}-\mathrm{C}_{6} \mathrm{H}_{4}, \mathrm{Ph}
$$<smiles>[R]N[R]N(C)C</smiles>

Scheme 5. Syntheses of secondary (12) and tertiary (13) aminonaphthols.

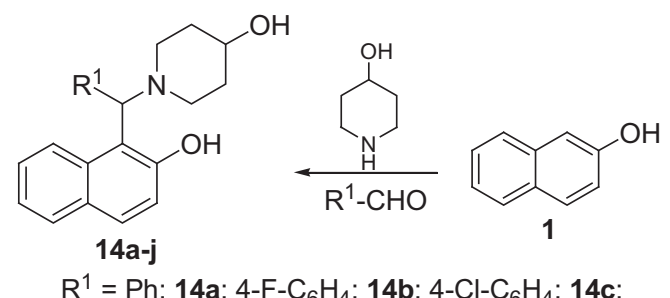

$\mathrm{R}^{1}=\mathrm{Ph}: 14 \mathrm{a} ; 4-\mathrm{F}-\mathrm{C}_{6} \mathrm{H}_{4}: 14 \mathrm{~b} ; 4-\mathrm{Cl}_{-} \mathrm{C}_{6} \mathrm{H}_{4}: 14 \mathrm{c}$;

4-Me- $\mathrm{C}_{6} \mathrm{H}_{4}: 14 \mathrm{~d} ; 4-\mathrm{OMe}-\mathrm{C}_{6} \mathrm{H}_{4}$ : 14e; 3,4-di-Cl- $\mathrm{C}_{6} \mathrm{H}_{3}:$ 14f;

3,4-di-OMe- $\mathrm{C}_{6} \mathrm{H}_{3}$ : 14g; 3,4-di-OMe- $\mathrm{C}_{6} \mathrm{H}_{3}$ : 14h;

4-py: 14i; 2-py: 14j

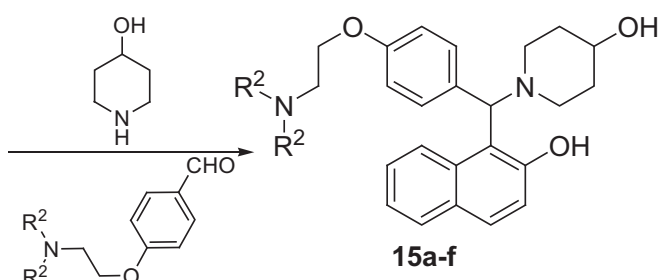

$\mathrm{N}\left(\mathrm{R}^{2}\right)_{2}=\mathrm{NMe}_{2}: 15 \mathrm{a} ; \mathrm{NEt}_{2}: 15 \mathrm{~b} ; \mathrm{N}(\operatorname{Pr})_{2}: 15 \mathrm{c} ;$ pyrrolidyl: 15d; piperidyl: 15e; morpholyl:15f

Scheme 6. Syntheses of 1-((2-hydroxynaphthalen-1-yl)arylmethyl)piperidin-4-ol derivatives.<smiles>[R]N1COc2c(ccc3ccccc23)C1</smiles>

16

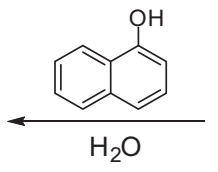

$2 \mathrm{CH}_{2} \mathrm{O}$

$\mathrm{R}=$ aryl, alkyl

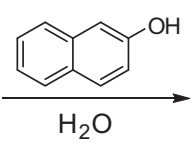<smiles>[R]N1COc2ccc3ccccc3c2C1</smiles>

17

Scheme 7. Aminoalkylation of 1- and 2-naphthols with primary amines and formaldehyde.

moiety when 2-naphthol (1) was aminoalkylated by using benzaldehyde (20c) and $(R)-(+)-1-(1-$ naphthyl)ethylamine (19c), $(R)-(+)-N$-methyl-1-(1-naphthyl)ethylamine (19d) or $(R)-(+)-1-(2-$ naphthyl)ethylamine (19e), resulting in 21c-e (Table 1$)$, while 21c and 21e were also transformed into 22c and 22e through cyclization with formaldehyde, followed by reduction with $\mathrm{LiAlH}_{4}{ }^{33}$

A series of new tertiary aminonaphthol ligands with diverse substituted groups $(\mathbf{2 2 f}-\mathbf{q})$ were prepared from 2-naphthol (1), $(S)-(-)-\alpha$-methylbenzylamine (19f) and aldehydes $(\mathbf{2 0 f}-\mathbf{q})$ via $\mathrm{N}-$ methylation of $\mathbf{2 1 f}-\mathbf{q}$ with formaldehyde followed by reduction with $\mathrm{NaBH}_{4}{ }^{34}$

The synthesis of enantiomerically pure naphthylglycinates $(21 \mathbf{r}-\mathbf{u})$ was achieved by the reaction between naphthol derivatives $(\mathbf{1}, \mathbf{4 a}$ and $\mathbf{1 8})$ and enantiopure $\alpha$-imino glyoxylate formed from $(R)-(+)-\alpha$-methylbenzylamine (19r) and ethyl glyoxylate (20r) (Table 1). ${ }^{35}$

A recent approach in the mMRs involves insertion of a chiral group into the final product by using non-racemic aldehydes. In this field, Palmieri et al. reported the stereoselective synthesis of vicinal aminodiols (26a-d), diamines (26e and 26f) and a diaminol (26g;
Table 2) starting from amines $\mathbf{2 3}$, non-racemic aldehydes (24) followed by removing the protecting groups of compounds $\mathbf{2 5}$. $^{36}$

Diastereoselective syntheses of chiral 1,2-diaminoalkylnaphthols 27-29 from an amine, chiral $\alpha-N, N$-dibenzylamino aldehyde and 1-or 2-naphthol were achieved by Rondot and Zhu. ${ }^{37}$ The diastereoselectivity of the reaction was found to depend on the temperature, with a low reaction temperature $\left(-20^{\circ} \mathrm{C}\right)$ favouring formation of the anti adduct, and higher temperature $\left(60^{\circ} \mathrm{C}\right)$ mainly that of the syn isomer (Scheme 8).

Through mMRs, a series of new aminonaphthol derivatives (30, Scheme 9) were prepared from 2-naphthol, aromatic aldehydes and heteroaryl amines in water at room temperature. A study of the enantiomeric resolution of $\mathbf{3 0}$ with the aid of ${ }^{1} \mathrm{H}$ NMR spectroscopy and use of a chiral europium shift reagent was also presented. ${ }^{38}$ The series of $N$-heteroaryl-substituted aminonaphthols was extended by using water as solvent ${ }^{39}$ or solvent-free conditions. ${ }^{40}$

An efficient and environmentally friendly approach for the synthesis of 2'-aminobenzothiazolomethyl-2-naphthols (32) via the condensation of an aromatic aldehyde, 2-naphthol and 2aminobenzothiazole (31) in water as solvent has been reported by Shaabani et al. (Scheme 10). ${ }^{41}$ 
I. Szatmári, F. Fülöp / Tetrahedron 69 (2013) 1255-1278

1259

Table 1

Syntheses of enantiopure aminonaphthols $\mathbf{2 1}$ and $\mathbf{2 2}$<smiles>Oc1ccc2ccccc2c1</smiles>

1

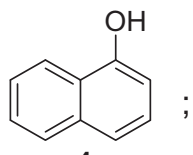

$4 a$

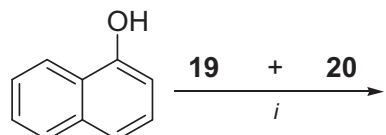

$18 \mathrm{OMe}$
$21 \stackrel{i i}{\longrightarrow}$

22 a
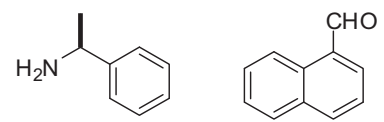

Solvent-free, $85^{\circ} \mathrm{C}, 72 \mathrm{~h}$

b
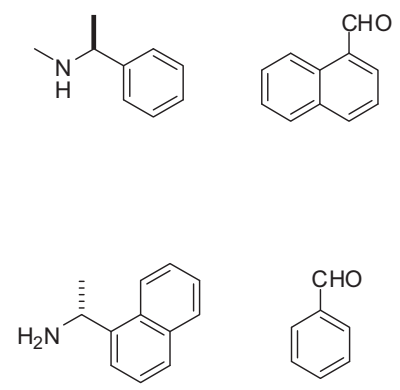

Solvent-free, $65^{\circ} \mathrm{C}, 72 \mathrm{~h}$

d
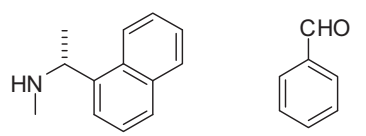

Solvent-free, $65^{\circ} \mathrm{C}, 72 \mathrm{~h}$

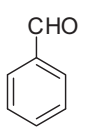

Solvent-free, $65^{\circ} \mathrm{C}, 72 \mathrm{~h}$

f
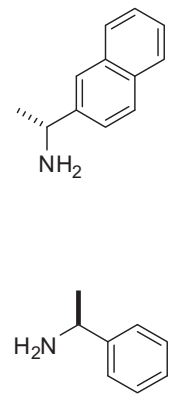<smiles>O=Cc1ccccc1</smiles>

Solvent-free, $60{ }^{\circ} \mathrm{C}, 8-36 \mathrm{~h}$

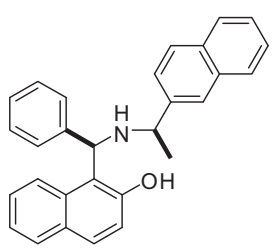

Solvent-free, $60{ }^{\circ} \mathrm{C}, 8-36 \mathrm{~h}$

g

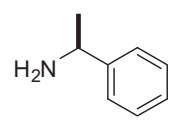<smiles>Cc1ccccc1C=O</smiles>

h<smiles>CC(N)c1ccccc1</smiles><smiles>Cc1cccc(C=O)c1</smiles>

1. $\mathrm{CH}_{2} \mathrm{O}$, rt

2. $\mathrm{LiAlH}_{4}$, rt
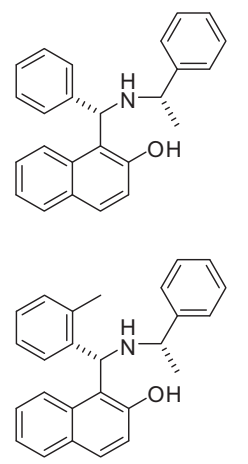

1. $\mathrm{CH}_{2} \mathrm{O}$, rt
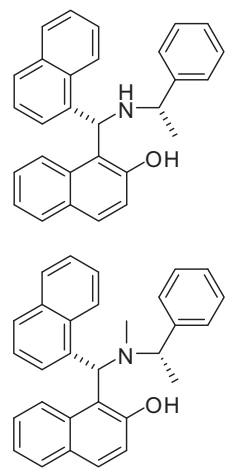

1. $\mathrm{CH}_{2} \mathrm{O}$, rt

1. $\mathrm{CH}_{2} \mathrm{O}, \mathrm{rt}$

2. $\mathrm{NaBH}_{4}, \mathrm{rt}$

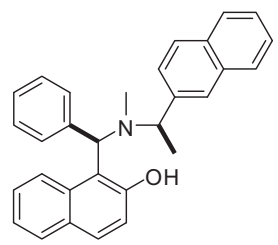

2. $\mathrm{NaBH}_{4}, \mathrm{rt}$

1. $\mathrm{CH}_{2} \mathrm{O}, \mathrm{rt}$

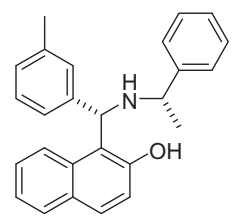

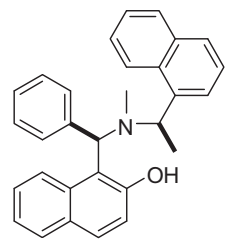

33

33

33

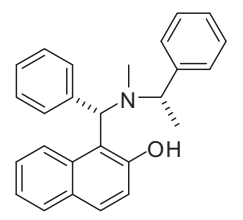

34

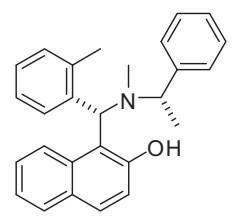

34

32

32
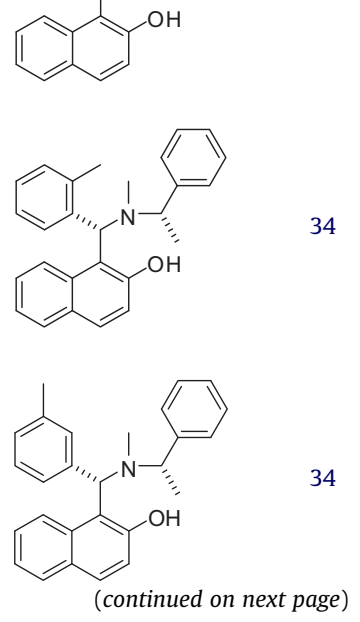
Table 1 (continued)

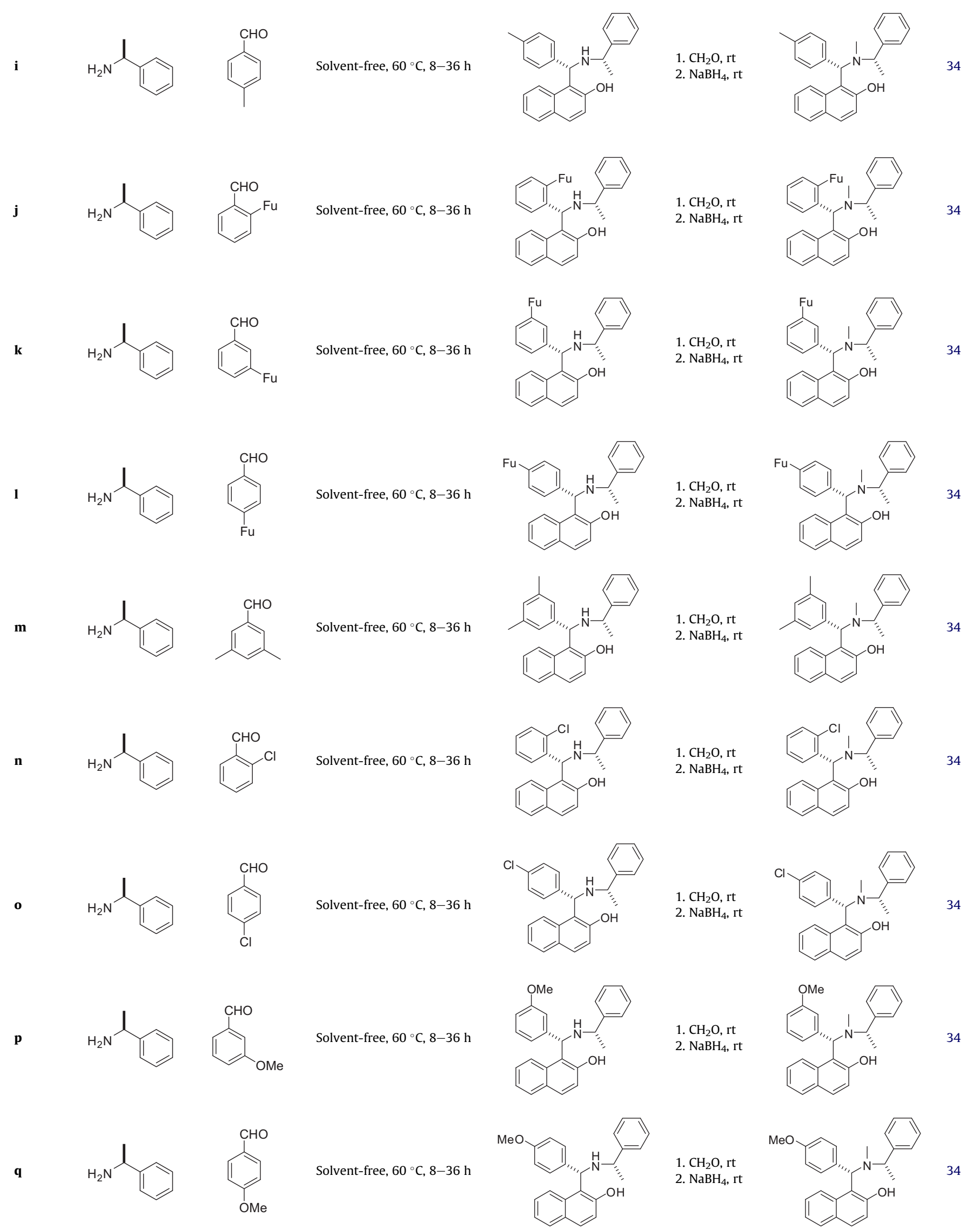


Table 1 (continued)

\begin{tabular}{|c|c|c|c|c|c|c|c|}
\hline Compd & Amine (19) & Aldehyde (20) & $i$ & 21 & $i i$ & 22 & Ref. \\
\hline $\mathbf{r}$ & $\mathrm{H}_{2} \mathrm{~N}^{-}$ & & Toluene, $-15^{\circ} \mathrm{C}, 3-10 \mathrm{~h}$ & & - & - & 35 \\
\hline $\mathbf{s}$ & $\mathrm{H}_{2} \mathrm{~N}^{-}$ & & Toluene, $-15^{\circ} \mathrm{C}, 3-10 \mathrm{~h}$ & & - & - & 35 \\
\hline $\mathbf{t}$ & $\mathrm{H}_{2} \mathrm{~N}^{-}$ & & Toluene, $-15^{\circ} \mathrm{C}, 3-10 \mathrm{~h}$ & & - & - & 35 \\
\hline $\mathbf{u}$ & & & Toluene, $-15^{\circ} \mathrm{C}, 3-10 \mathrm{~h}$ & & - & - & 35 \\
\hline
\end{tabular}

\section{Table 2}

Syntheses of aminodiols and diaminoalcohols $\mathbf{2 5}$ and $\mathbf{2 6}$

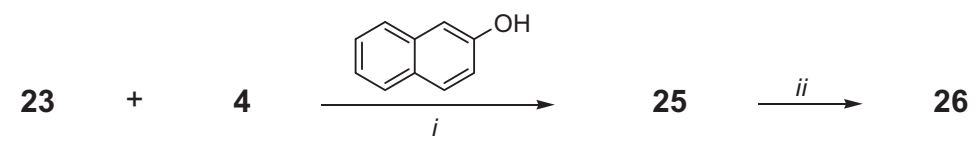

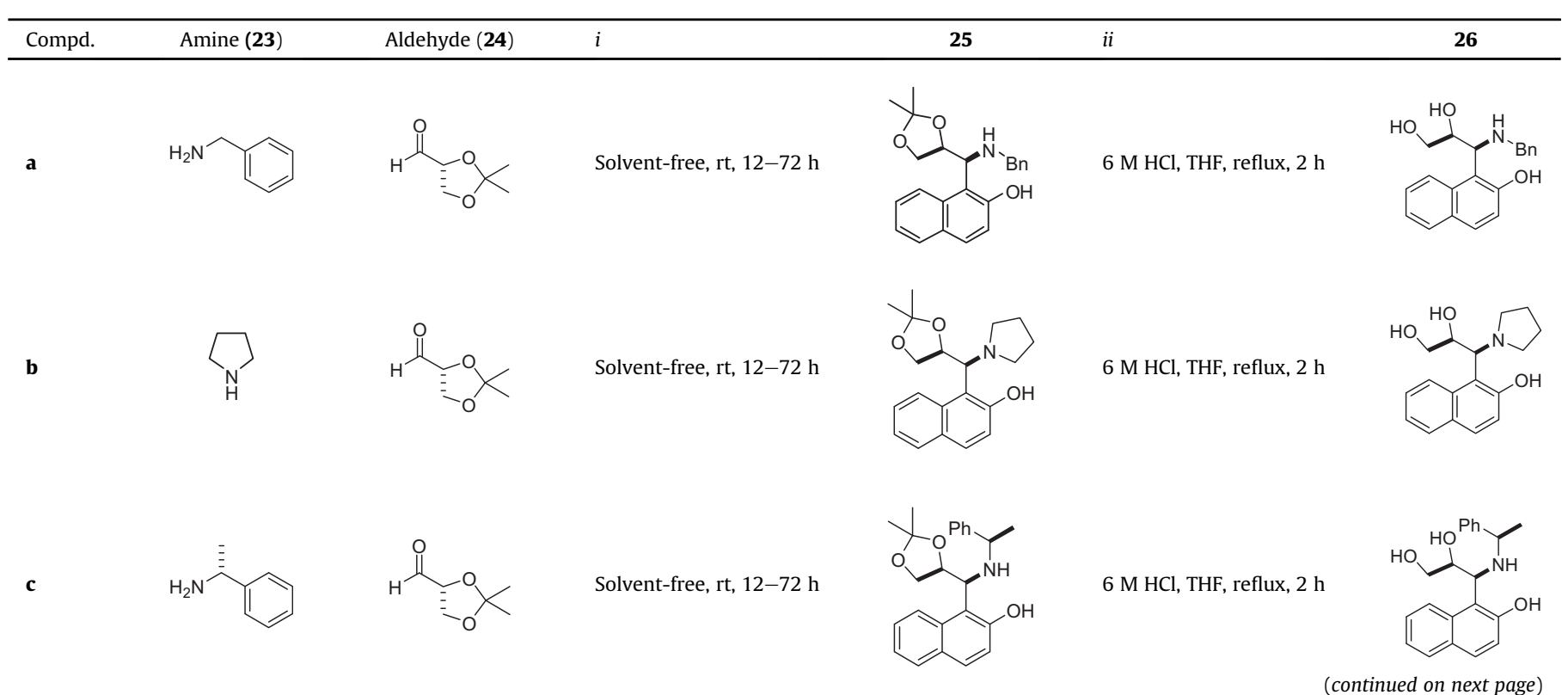


Table 2 (continued)

\begin{tabular}{|c|c|c|c|c|c|c|}
\hline Compd. & Amine (23) & Aldehyde (24) & $i$ & 25 & $i i$ & 26 \\
\hline d & & & Solvent-free, rt, $12-72 \mathrm{~h}$ & & $6 \mathrm{M} \mathrm{HCl}, \mathrm{THF}$, reflux, $2 \mathrm{~h}$ & \\
\hline e & $\mathrm{H}_{2} \mathrm{~N}$ & & Solvent-free, rt, $12-72 \mathrm{~h}$ & & $6 \mathrm{M} \mathrm{HCl}$, THF, reflux, $2 \mathrm{~h}$ & \\
\hline f & & & Solvent-free, rt, $12-72 \mathrm{~h}$ & & $6 \mathrm{M} \mathrm{HCl}, \mathrm{THF}$, reflux, $2 \mathrm{~h}$ & \\
\hline g & & & Solvent-free, rt, $12-72 \mathrm{~h}$ & & $6 \mathrm{M} \mathrm{HCl}$, THF, reflux, $2 \mathrm{~h}$ & \\
\hline
\end{tabular}<smiles>[R]NC(c1cc([X])c2ccccc2c1O)C([R])CCC</smiles>

$\mathrm{X}=\mathrm{H}: \mathbf{2 7} ; \mathrm{OMe}: 28$

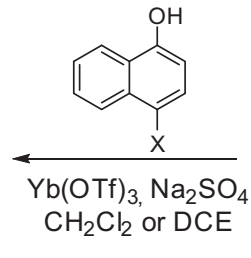

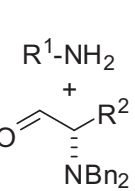

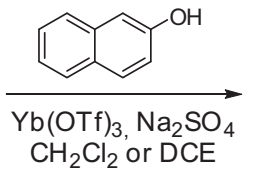
$\mathrm{CH}_{2} \mathrm{Cl}_{2}$ or DCE

$\mathrm{NBn}_{2}$

$$
\begin{gathered}
\mathrm{R}^{1}=\mathrm{Bn}, \mathrm{CH}_{2}-\mathrm{CH}_{2} \text {-OTBS, 4-OMe- } \mathrm{C}_{6} \mathrm{H}_{4} \\
\mathrm{R}^{2}=\mathrm{Me}, \mathrm{Bn}, \mathrm{CH}_{2} \text {-OTBS }
\end{gathered}
$$

Scheme 8. Syntheses of non-racemic diaminonaphthols 27-29.<smiles>[R17]NC(C([R])N)C(c1c(O)ccc2ccccc12)C([R])N</smiles>

29<smiles>[R][R]NC([R])c1c(O)ccc2ccccc12</smiles>

Scheme 9. Aminoalkylation of 2-naphthol with heteroaryl amines and aromatic aldehydes.

The preparation of novel bis-aminonaphthol derivatives is another new approach in the chemistry of the mMR. 2,6Dihydroxynaphthalene (33) can be interpreted as an electron-rich aromatic system with two activated positions. When it was reacted with 2 equiv of aromatic aldehyde and 2 equiv of cyclic amine (piperidine or morpholine 34), 35a-d could be isolated (Scheme 11) ${ }^{42}$
Synthesis of the bis-product $\mathbf{3 6}$ was achieved from 2-naphthol, (S)-(-)- $\alpha$-methylbenzylamine and $m$-phthalaldehyde, ${ }^{43,44}$ and it was transformed into 37 by reaction with 2,6-bis-(chloromethyl) pyridine (Scheme 12). ${ }^{45}$

Jha et al. reported the syntheses of the bis-Mannich bases 38a-1 and 39a,b of 2-naphthol, derived from aromatic aldehydes and 
<smiles>Oc1ccc2ccccc2c1</smiles>

1

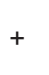<smiles>Nc1nc2ccccc2s1</smiles>

31<smiles>[X]c1ccc(C(Nc2nc3ccccc3s2)c2c(O)ccc3ccccc23)cc1</smiles>

32

$\mathrm{X}=\mathrm{H}, 4-\mathrm{Me}, 4-\mathrm{OMe}, 4-\mathrm{Cl}, 3-\mathrm{NO}_{2}$

Scheme 10. Syntheses of $2^{\prime}$-aminobenzothiazolomethyl-2-naphthols 32.<smiles>[X]C1CCNCC1</smiles>

35

\section{a}

b

c

d

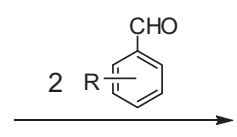

$\mathrm{R}$

$\mathrm{CH}_{2} \quad 3-\mathrm{CN}$

$\mathrm{CH}_{2} \quad 4-\mathrm{CN}$

$\mathrm{O} \quad 3-\mathrm{CN}$

O $\quad 4-\mathrm{CN}$

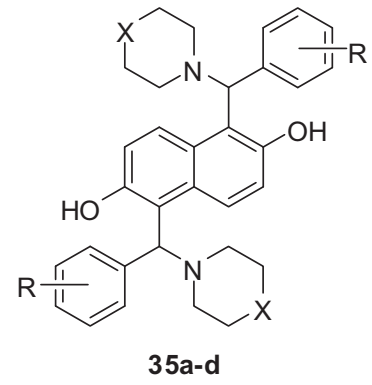

Scheme 11. Syntheses of bis-aminonaphthol derivatives 35 .

2<smiles>CC(C)=CC=O</smiles>
1<smiles>CC(N[C@H](c1ccccc1)c1cccc(C(N[C@@H](C)c2ccccc2)c2c(O)ccc3c2C=CCC3)c1)c1cccc2ccccc12</smiles>

36<smiles>ClCc1cccc(CCl)n1</smiles>
$\mathrm{DMF}, \mathrm{rt}$ D<smiles>CC(N[C@H](c1ccccc1)c1cccc(C(N[C@@H](C)c2ccccc2)c2c(OCc3ccccc3)ccc3ccccc23)c1)c1c(OCc2ccccc2)ccc2ccccc12</smiles>

37

Scheme 12. Syntheses of enantiopure aminonaphthols $\mathbf{3 6}$ and $\mathbf{3 7 .}$

diamines such as piperazine and $N, N^{\prime}$-dialkylethylenediamines. Although refluxing in ethanol provided products with higher purity, the use of microwave-assisted conditions was found to be the most efficient method of synthesizing these compounds in terms of atom economy, energy consumption and time required (Scheme 13). ${ }^{46}$

2.2.2. Syntheses from quinolinol or isoquinolinol derivatives. The reaction of $\mathbf{4 0}$ with dimethylamine in the presence of formaldehyde led to Mannich base $\mathbf{4 1}$ together with by-product $\mathbf{4 2}$. The results and the analytical data indicated that the structure of 42 is $1,1^{\prime}$ dichloro-3,3'-methylenedi(4-isoquinolinol) (Scheme 14). ${ }^{47}$

On the use of primary amines with 2 equiv of formaldehyde, cyclization of the Mannich bases formed led to $\mathbf{4 3 a}$ and $\mathbf{4 3 b} .{ }^{47}$

Möhrle and Miller applied an mMR to prepare $\mathbf{4 4 a}$ (Scheme 15) from 8-quinolinol (4b), formaldehyde and piperidine as a cyclic secondary amine, or $\mathbf{4 4 b}$ when formaldehyde was replaced by benzaldehyde. ${ }^{48}$ 6-Isoquinolinol (45) was successfully aminoalkylated with the iminium salt of morpholine and benzaldehyde prepared in situ in the presence of lithium perchlorate in diethyl ether, yielding $\mathbf{4 6} .^{49}$

Electron-rich aromatic compounds such as 2-naphthol can be easily aminoalkylated with (R)-1-phenylethylamine (47) and benzaldehyde. The diastereoselectivity of the reaction has been explained in terms of an asymmetric transformation of the second kind induced by the preferential crystallization. ${ }^{50}$ In comparison with 2-naphthol, the less reactive 8-quinolinol (4b) gave 48 in moderate yield (44\%) and with poor $\mathrm{dr}$ (1.4). The reaction was performed under solvent-free conditions in which a mixture of 8quinolinol, $(R)$-1-phenylethylamine and benzaldehyde in a molar ratio of 1.0:1.05:1.2 was stirred and heated at $60{ }^{\circ} \mathrm{C}$ for the time required, under an inert atmosphere (Scheme 16)..$^{50}$

The mMRs of anilines, benzaldehydes and 8-quinolinols yielded 7 $\alpha$-anilinobenzyl-8-quinolinols $\mathbf{5 0}$ (Scheme 17). ${ }^{51-54}$ The simplicity of these three-component reactions led to the combination of aliphatic aldehydes and substituted anilines (49) to obtain 7-anilinoalkyl-8- 

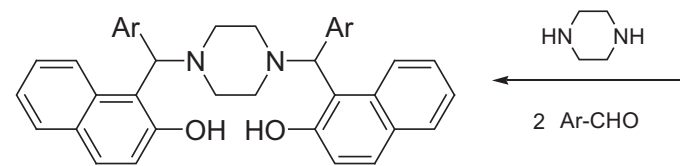

2<smiles>Oc1ccc2ccccc2c1</smiles>

1
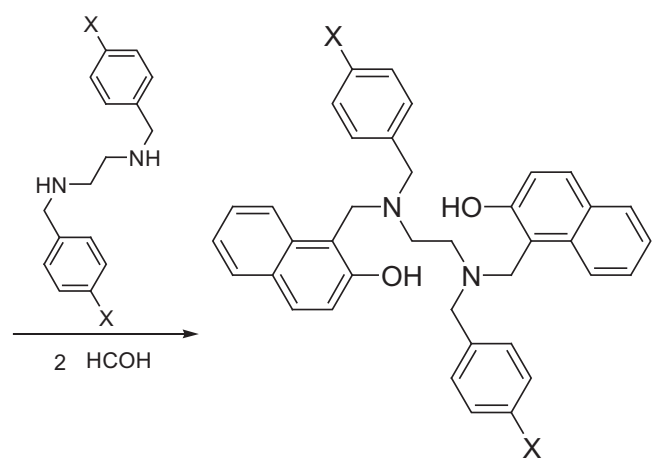

$X=H: 39 a ; M e: 39 b$

38: $\mathrm{Ar}=\mathrm{Ph}: \mathbf{a} ; 4-\mathrm{Me}_{-} \mathrm{C}_{6} \mathrm{H}_{4}: \mathbf{b} ; 4-\mathrm{F}-\mathrm{C}_{6} \mathrm{H}_{4}: \mathbf{c} ; 4-\mathrm{Cl}_{-} \mathrm{C}_{6} \mathrm{H}_{4}: \mathbf{d}$; 4-OMe- $\mathrm{C}_{6} \mathrm{H}_{4}: \mathbf{e} ; 4-\mathrm{NO}_{2}-\mathrm{C}_{6} \mathrm{H}_{4}: \mathbf{f} ; 4-\mathrm{NMe}_{2}-\mathrm{C}_{6} \mathrm{H}_{4}: \mathbf{g} ; 3,4-d i-\mathrm{Cl}_{3} \mathrm{C}_{6} \mathrm{H}_{3}: \mathbf{h}$; 3,4-di-OMe- ${ }_{6} \mathrm{H}_{3}: \mathbf{i} ; 3,4-\mathrm{OCH}_{2} \mathrm{O}-\mathrm{C}_{6} \mathrm{H}_{3}: \mathbf{j}$; 4-py: k; 2-py: I

Scheme 13. Aminoalkylation of 2-naphthol with symmetric diamines and aldehydes.<smiles></smiles>

$\mathrm{R}=\mathrm{H}: 44 \mathrm{a}$ $\mathrm{R}=\mathrm{Ph}: \mathbf{4 4 b}$<smiles>CCCN(C)Cc1nc(Cl)c2ccccc2c1O</smiles>

41<smiles>COc1ccc2c(Cl)ncc(O)c2c1</smiles>

40<smiles>[R]N1COc2c(nc(Cl)c3ccccc23)C1</smiles>

$R=$ Me: 43a;

$\mathrm{Ph}:$ 43b

Scheme 14. Aminoalkylation of 1-chloro-4-isoquinolinol.

Scheme 15. Syntheses of tertiary aminoquinolinol and aminoisoquinolinol.<smiles>Oc1cccc2cccnc12</smiles>

$4 b$

$\mathrm{OH}$<smiles>Oc1cccc2ccccc12</smiles><smiles>[R]C[Z]1CCNCC1</smiles><smiles>Oc1ccc2cnccc2c1</smiles>

$\mathrm{X}=\mathrm{CH}_{2}$ or $\mathrm{O}$<smiles>Oc1ccc2cnccc2c1C(c1ccccc1)N1CCOCC1</smiles>

46

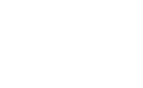<smiles>C1CCCCC1</smiles><smiles>CC(N)c1ccccc1</smiles>

47

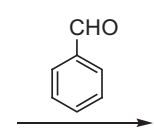<smiles>C[C@H](NC(c1ccccc1)c1ccc2cccnc2c1O)c1ccccc1</smiles>

48

Scheme 16. Synthesis of non-racemic aminoquinolinol 48.
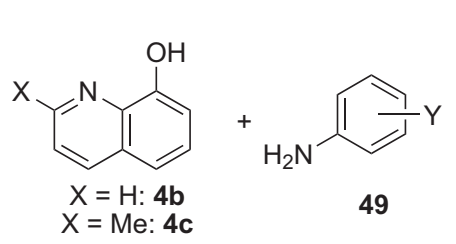<smiles>[R]OC1CC1</smiles><smiles>[Y]c1ccc(NC([R])c2ccc3ccc([X])nc3c2O)cc1</smiles>

50

$$
\mathrm{X}=\mathrm{H}, \mathrm{Me}
$$

$\mathrm{Y}=\mathrm{H}, 2-\mathrm{NO}_{2}$, 3- $\mathrm{NO}_{2}, 4-\mathrm{NO}_{2}$, 2-Cl, 3-Cl, 4-Cl, 3-F, 4-Cl,2- $\mathrm{NO}_{2}$, 2-Me, 4-Me, 3-Et, 2-OMe, 4-OMe, 2-OEt, 4-OEt, 2-COOH, 2-COOEt, 4-COOH, 4-COOnPr, 4-COOnBu

$\mathrm{R}=\mathrm{Me}_{3}\left(\mathrm{CH}_{2}\right)_{5}-, \mathrm{Me}_{3}\left(\mathrm{CH}_{2}\right)_{2}-, \mathrm{Ph}, 2-\mathrm{OH}-\mathrm{C}_{6} \mathrm{H}_{4}, 3-\mathrm{OH}-\mathrm{C}_{6} \mathrm{H}_{4}, 4-\mathrm{OMe}-\mathrm{C}_{6} \mathrm{H}_{4}, 3-\mathrm{NO}_{2}-\mathrm{C}_{6} \mathrm{H}_{4}$, 4-i $\mathrm{Pr}-\mathrm{C}_{6} \mathrm{H}_{4}, 6-\mathrm{Br}, 3-\mathrm{OH}-\mathrm{C}_{6} \mathrm{H}_{3}, 3-\mathrm{OMe}, 4-\mathrm{OH}-\mathrm{C}_{6} \mathrm{H}_{3}, 5-\mathrm{Br}, 3-\mathrm{OMe}, 4-\mathrm{OH}-\mathrm{C}_{6} \mathrm{H}_{2}$, 2-furyl, 2-py

Scheme 17. Syntheses of 7-arylaminomethyl-substituted 8-quinolinol derivatives. 
quinolinols. ${ }^{53,55}$ The aminoalkylation was extended to the use of $\mathbf{4 b}$ and $\mathbf{4 c}$ as electron-rich aromatic compounds. ${ }^{53,55-57}$

Hamachi et al. carried out the addition of 8-quinolinol (4b) to the Schiff bases formed from 2-pyridinecarboxaldehyde and different substituted aniline derivatives. The procedure was very simple and involved an ethanolic solution of equivalent amounts of the Schiff base and 8-quinolinol being allowed to stand at room temperature, when the desired 7-substituted quinolinols were obtained in good-to-excellent yields. ${ }^{58}$

The series of anilines was extended with anthranilic acid and ethyl anthranilate, ${ }^{54}$ or with a series of $p$-aminobenzoates (Scheme 17), ${ }^{59}$ yielding the desired Mannich products $\mathbf{5 0 .}$

Sulphonamides $\mathbf{5 1}$ are special substituted aniline derivatives of established therapeutic importance. Their reactions with 8-quinolinol in the presence of acetaldehyde or benzaldehyde furnished 7-substituted-8-hydroxyquinolines (52) (Scheme 18). ${ }^{60,61}$

\subsection{Aza-Friedel-Crafts reactions of naphthol derivatives with imines}

The aza-Friedel-Crafts reactions of naphthol derivatives with different imines can be interpreted as a special variant of the mMR.

The enantioselective reactions of 2-naphthol or its 6-substituted derivatives and 1-naphthol or its 4-substituted derivatives with $\mathrm{N}$-sulphonyl imines were recently achieved by catalysis with cinchona-derived compounds. The Mannich products obtained (61 and 62, Scheme 22) were isolated with good-to-excellent ee. ${ }^{62,63}$

The present authors reported the first syntheses of 1-(hydroxynaphthyl)-substituted 1,2,3,4-tetrahydroisoquinolines (64a-c and 65a,b, Table 3), in which 1- or 2-naphthol was reacted with 3,4dihydroisoquinolines (63) either in MeCN or under solvent-free conditions with microwave irradiation. ${ }^{64}$ A Canadian research group later described the syntheses of some 1-(hydroxynaphthyl)-<smiles>[R][R]C(C)Oc1nc(C)cc(OC)n1</smiles>

Scheme 18. Syntheses of 7-substituted 8-quinolinol derivatives containing a sulphonamide moiety.

The reaction of $\mathbf{4 b}$, benzaldehyde and aniline has been extended to heteroaromatic amines (53) such as 2-amino-3-methylpyridine, 2-amino-4-methylpyridine, 2-amino-5-methylpyridine, 2-amino6-methylpyridine, 2,6-diaminopyridine, 2-aminobenzothiazole, 2aminothiazole, 2-aminobenzimidazole and 3-aminoquinoline, leading to 54 (Scheme 19). ${ }^{53}$ It is interesting to note that 2,6- substituted 1,2,3,4-tetrahydroisoquinoline derivatives (64a,d-n) by the same route, but with some modifications. ${ }^{65,66}$ Compounds 640-t were prepared in enantiomerically pure form from 2-naphthol analogues and $(R)$-3-phenyl-3,4-dihydroisoquinoline. The arrangement of the naphthyl and $R^{2}$ substituents in $640-t$ was found to be cis (Table 3$)^{67}$

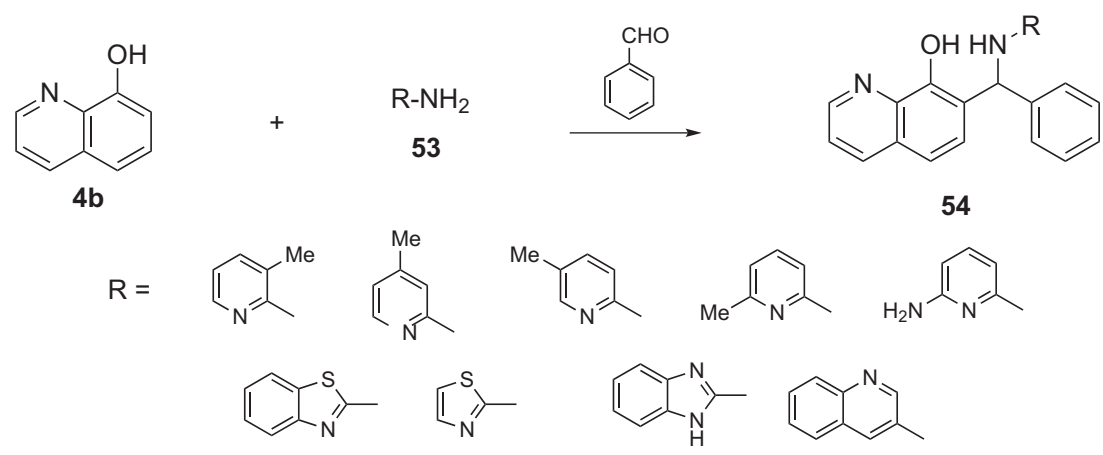

Scheme 19. Aminoalkylation of 8-quinolinol with primary amines and benzaldehyde.

diaminopyridine appeared to react at only one amino group. ${ }^{11}$

Shaabani et al. devised an efficient and environmentally friendly approach for the synthesis of 5-(2'-aminobenzothiazolomethyl)-6hydroxyquinolines (Scheme 20, 56) via the condensation of a substituted benzaldehyde, 6-quinolinol (55) and 2aminobenzothiazole (31) in water as solvent. In the presence of ionic solutes such as $\mathrm{LiCl}, \mathrm{NaCl}, \mathrm{NaNO}_{3}, \mathrm{Na}_{2} \mathrm{SO}_{4}, \mathrm{LiNO}_{3}$ or $\mathrm{Li}_{2} \mathrm{SO}_{4}$, the yields of the reactions were improved. ${ }^{41}$

The reactions of $\mathbf{4 b}$ with substituted oxazoles (57) and thiazoles (58) in the presence of benzaldehyde led to the Mannich bases 59 and 60, as depicted in Scheme 21 . $^{12}$
The solvent-free syntheses of 1-hydroxyquinolyl- and 1hydroxyisoquinolyl-1,2,3,4-tetrahydroisoquinoline derivatives (66 and 67, Scheme 23) from $N$-containing 1-naphthol or 2-naphthol derivatives were achieved through 3,4-dihydroisoquinolines (63) using classical heating at $80-100{ }^{\circ} \mathrm{C}$ or microwave agitation at the same temperature. Both reaction conditions yielded the products in good yields (57-92\%), but the use of microwave conditions allowed a decrease of the reaction time from $10-50 \mathrm{~h}$ to $1.5-3.5 \mathrm{~h}^{68}$

The reaction has been extended by starting from five- and sixmembered cyclic imines $(\mathbf{6 8 a}, \mathbf{6 8 b})$ and 1- or 2-naphthol analogues to give $\mathbf{6 9 a}, \mathbf{b}$ and $\mathbf{7 1 a , b}$, or from 3,4-dihydroisoquinoline 
<smiles>Oc1ccc2ncccc2c1</smiles>

55

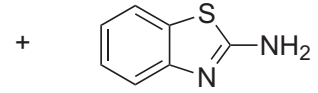

31

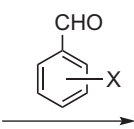<smiles>[X]c1ccc(C(NC(=N)S)c2c(O)ccc3ncccc23)cc1</smiles>

56

$\mathrm{X}=\mathrm{H}, 4-\mathrm{Me}$, 4-OMe, 4-Cl, 4-Br, 3-OMe, 3- $\mathrm{NO}_{2}$

Scheme 20. Aminoalkylation of 6-quinolinol with aminobenzothiazole and substituted benzaldehydes.<smiles>Oc1cccc2cccnc12</smiles>

$4 \mathrm{~b}$

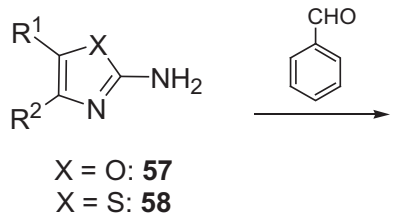

$\mathrm{R}^{1}=\mathrm{H}, \mathrm{Cl}, \mathrm{Br}$;

$\mathrm{R}^{2}=\mathrm{Ph}, 4-\mathrm{Cl}-\mathrm{C}_{6} \mathrm{H}_{4}, 4-\mathrm{Br}_{-} \mathrm{C}_{6} \mathrm{H}_{4}, 4-\mathrm{OH}-\mathrm{C}_{6} \mathrm{H}_{4}, 4-\mathrm{OMe}-\mathrm{C}_{6} \mathrm{H}_{4}, 4-\mathrm{Me}^{-} \mathrm{C}_{6} \mathrm{H}_{4}$,

3- $\mathrm{NO}_{2}-\mathrm{C}_{6} \mathrm{H}_{4}, 4-\mathrm{NO}_{2}-\mathrm{C}_{6} \mathrm{H}_{4}, 4-\mathrm{Me}_{2}-\mathrm{C}_{6} \mathrm{H}_{4}, 1-\mathrm{Nph}, 2-\mathrm{Nph}$

Scheme 21. Syntheses of 7-substituted 8-quinolinol derivatives containing an oxazole or thiazole moiety.<smiles></smiles>

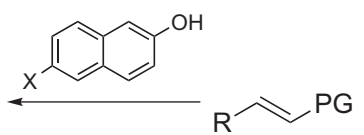

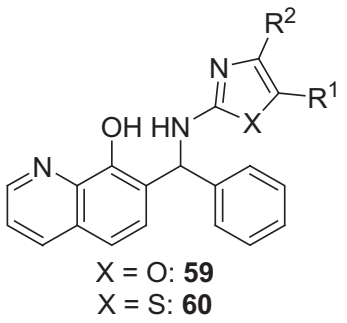

$\mathrm{X}=\mathrm{S}: 60$

\footnotetext{
61

$\mathrm{X}=\mathrm{H}, \mathrm{Br}, \mathrm{OMe} ; \quad \mathrm{Y}=\mathrm{H}, \mathrm{Cl}, \mathrm{OMe}$

$P G=T s, B s, B o c$

$\mathrm{R}=\mathrm{Ph}, 2-\mathrm{F}-\mathrm{C}_{6} \mathrm{H}_{4}, 4-\mathrm{F}-\mathrm{C}_{6} \mathrm{H}_{4}, 2-\mathrm{Me}_{-} \mathrm{C}_{6} \mathrm{H}_{4}, 4-\mathrm{Me}-\mathrm{C}_{6} \mathrm{H}_{4}, 2-\mathrm{Cl}-\mathrm{C}_{6} \mathrm{H}_{4}, 3-\mathrm{Cl}-\mathrm{C}_{6} \mathrm{H}_{4}, 4-\mathrm{Cl}-\mathrm{C}_{6} \mathrm{H}_{4}, 2-\mathrm{OMe}_{6}-\mathrm{C}_{6} \mathrm{H}_{4}$, 4-OMe- $\mathrm{C}_{6} \mathrm{H}_{4}, 4-\mathrm{Br}_{-} \mathrm{C}_{6} \mathrm{H}_{4}, 2-\mathrm{NO}_{2}-\mathrm{C}_{6} \mathrm{H}_{4}, 3-\mathrm{NO}_{2}-\mathrm{C}_{6} \mathrm{H}_{4}, 4-\mathrm{NO}_{2}-\mathrm{C}_{6} \mathrm{H}_{4}, 2-\mathrm{Nph}$, furyl, i-Pr, $\mathrm{Pr}, n-\mathrm{Bu}$
}

Scheme 22. Syntheses of aminonaphthols $\mathbf{6 1}$ and $\mathbf{6 2}$ from naphthol analogues and imines.

(68c) and 4-methoxy-1-naphthol or 2-naphthol to give 70c and 71c, respectively (Scheme 24). The absolute configurations of 69a and 69b were ascertained by X-ray analysis and chiroptical methods (ECD) after resolution of the corresponding racemates with $(R, R)$-tartaric acid. Additionally, all the prepared racemic compounds (69-71) were transformed into their $N$-methylated derivatives (72-74) by using formaldehyde, followed by reduction with $\mathrm{NaBH}_{4} \cdot{ }^{69}$

\section{Applications of Mannich bases synthesized via mMRs}

\subsection{Transformations of aminonaphthol derivatives}

Thanks to the two or more functional groups present in the structures of the Mannich bases prepared via mMR (as presented in Section 2.2), such transformations have become a highly important field of application of these aminonaphthol derivatives.
The present authors condensed 3d,o-r with substituted benzaldehydes with the aid of microwave irradiation to obtain 1-alkyl-3aryl-2,3-dihydro-1H-naphth[1,2-e][1,3]oxazines $(\mathbf{7 5}(\mathbf{a}-\mathbf{g})-\mathbf{7 9}(\mathbf{a}-\mathbf{g})$, Scheme 25), which proved to be three-component tautomeric mixtures in $\mathrm{CDCl}_{3}$ at $300 \mathrm{~K}$, involving $\mathrm{C}-3$ epimeric naphthoxazines (B and C) besides the open tautomer $(\mathbf{A}){ }^{21}$ These compounds served as an excellent model system for further study of the influence of the double substituents on the tautomeric equilibria of disubstituted naphthoxazines. Quantitative investigations of the ring-chain tautomeric equilibria of 1,3-diaryl-2,3-dihydro- $1 H$-naphth[1,2-e][1,3]oxazines have recently led to the first precise mathematical formulae with which to characterize the effects of substituents situated elsewhere than between the heteroatoms. It was demonstrated, for example, that the tautomeric ratio was influenced not only by the aryl substituent at position-3, but also by that at position- 1 . The additional stabilization effect was explained as an anomeric effect in the trans ring form. ${ }^{70-72}$ The results of multiple linear regression analysis of the $\log K_{\mathrm{R}}$ values of the tautomeric equilibria of 3-alkyl-1-aryl-2,3- 
Table 3

Aza-Friedel-Crafts reaction between naphthols and dihydroisoquinolines<smiles>[R]c1cc2c(cc1[R])C(c1c(O)c([R])c([R])c3cc([R])c([R])cc13)NC([R])C2</smiles>

64a-n<smiles>[R]c1cc2cc(O)c([R])c([R])c2cc1[R8]</smiles><smiles>C1CCC1</smiles><smiles>[R]C1CCCC1</smiles><smiles>[R]c1cc2c(cc1[R])CC([R])N=C2</smiles>

63<smiles>[R]c1cc2c(cc1[R])C(c1ccc3ccccc3c1O)NC([R])C2</smiles>

65

\begin{tabular}{|c|c|c|c|c|c|c|c|}
\hline Products & $\mathrm{R}^{1}$ & $\mathrm{R}^{2}$ & $\mathrm{R}^{3}$ & $\mathrm{R}^{4}$ & $\mathrm{R}^{5}$ & $\mathrm{R}^{6}$ & Ref. \\
\hline $64 a$ & $\mathrm{H}$ & $\mathrm{H}$ & $\mathrm{H}$ & $\mathrm{H}$ & $\mathrm{H}$ & $\mathrm{H}$ & 64,65 \\
\hline $64 b$ & OMe & $\mathrm{H}$ & $\mathrm{H}$ & $\mathrm{H}$ & $\mathrm{H}$ & $\mathrm{H}$ & 64 \\
\hline $64 c$ & OMe & Me & $\mathrm{H}$ & $\mathrm{H}$ & $\mathrm{H}$ & $\mathrm{H}$ & 64 \\
\hline 64d & $\mathrm{H}$ & $\mathrm{H}$ & $\mathrm{H}$ & $\mathrm{H}$ & OMe & $\mathrm{H}$ & 65 \\
\hline $64 \mathrm{e}$ & $\mathrm{H}$ & $\mathrm{H}$ & OMe & $\mathrm{H}$ & $\mathrm{H}$ & $\mathrm{H}$ & 65 \\
\hline $64 f$ & $\mathrm{H}$ & $\mathrm{H}$ & $\mathrm{H}$ & $\mathrm{H}$ & $\mathrm{H}$ & OMe & 65 \\
\hline $64 \mathrm{~g}$ & $\mathrm{H}$ & $\mathrm{H}$ & $\mathrm{H}$ & $\mathrm{H}$ & $-\mathrm{COPh}$ & $\mathrm{H}$ & 65 \\
\hline $64 h$ & $\mathrm{H}$ & $\mathrm{H}$ & $\mathrm{H}$ & $\mathrm{H}$ & $\mathrm{Br}$ & $\mathrm{H}$ & 65 \\
\hline $64 i$ & $\mathrm{H}$ & $\mathrm{H}$ & $\mathrm{COOH}$ & $\mathrm{H}$ & $\mathrm{H}$ & $\mathrm{H}$ & 66 \\
\hline $64 j$ & $\mathrm{H}$ & $\mathrm{H}$ & $\mathrm{CH}_{2} \mathrm{OH}$ & $\mathrm{H}$ & $\mathrm{H}$ & $\mathrm{H}$ & 66 \\
\hline $64 k$ & $\mathrm{H}$ & $\mathrm{H}$ & $\mathrm{OH}$ & $\mathrm{H}$ & $\mathrm{H}$ & $\mathrm{H}$ & 66 \\
\hline 641 & $\mathrm{H}$ & $\mathrm{H}$ & $\mathrm{H}$ & $\mathrm{H}$ & $\mathrm{H}$ & $\mathrm{OH}$ & 66 \\
\hline $64 m$ & $\mathrm{H}$ & $\mathrm{H}$ & $\mathrm{H}$ & $\mathrm{OH}$ & $\mathrm{H}$ & $\mathrm{H}$ & 66 \\
\hline $64 n$ & $\mathrm{H}$ & $\mathrm{H}$ & $\mathrm{H}$ & $\mathrm{H}$ & $\mathrm{H}$ & $\mathrm{H}$ & 66 \\
\hline$(1 S, 3 R)-\mathbf{6 4 0}$ & $\mathrm{H}$ & $\mathrm{Ph}$ & $\mathrm{Ph}$ & $\mathrm{H}$ & $\mathrm{H}$ & $\mathrm{H}$ & 67 \\
\hline$(1 S, 3 R)-\mathbf{6 4} \mathbf{p}$ & $\mathrm{H}$ & $\mathrm{Ph}$ & $4-\mathrm{OMe}-\mathrm{C}_{6} \mathrm{H}_{4}$ & $\mathrm{H}$ & $\mathrm{H}$ & $\mathrm{H}$ & 67 \\
\hline$(1 S, 3 R)-\mathbf{6 4 q}$ & $\mathrm{H}$ & $\mathrm{Ph}$ & $3-\mathrm{OMe}-\mathrm{C}_{6} \mathrm{H}_{4}$ & $\mathrm{H}$ & $\mathrm{H}$ & $\mathrm{H}$ & 67 \\
\hline$(1 S, 3 R)-\mathbf{6 4} \mathbf{r}$ & $\mathrm{H}$ & $\mathrm{Ph}$ & $3,5-\mathrm{Di}-(t-\mathrm{Bu})-\mathrm{C}_{6} \mathrm{H}_{3}$ & $\mathrm{H}$ & $\mathrm{H}$ & $\mathrm{H}$ & 67 \\
\hline$(1 S, 3 R)-\mathbf{6 4 s}$ & $\mathrm{H}$ & $\mathrm{Ph}$ & 2-Nph & $\mathrm{H}$ & $\mathrm{H}$ & $\mathrm{H}$ & 67 \\
\hline$(1 S, 3 R)-64 t$ & $\mathrm{H}$ & $\mathrm{Ph}$ & $\mathrm{CH}_{2} \mathrm{OH}$ & $\mathrm{H}$ & $\mathrm{H}$ & $\mathrm{H}$ & 67 \\
\hline 65a & $\mathrm{H}$ & $\mathrm{H}$ & $\mathrm{H}$ & $\mathrm{H}$ & $\mathrm{H}$ & $\mathrm{H}$ & 64,65 \\
\hline $65 b$ & OMe & $\mathrm{H}$ & $\mathrm{H}$ & $\mathrm{H}$ & $\mathrm{H}$ & $\mathrm{H}$ & 64 \\
\hline
\end{tabular}<smiles>[R]c1[Z]c2c(O)c(C3NCCc4cc([R])c([R])cc43)c[Y]c2c[Y]1C</smiles>

66

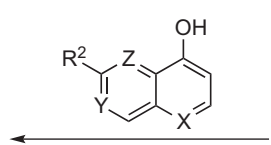<smiles>CCCC</smiles><smiles>[R1]c1cc2c(cc1[R1])CCN=C2</smiles><smiles></smiles>

63

$\mathrm{X}, \mathrm{Y}, \mathrm{Z}=\mathrm{CH}, \mathrm{N}$

$\mathrm{R}^{1}=\mathrm{H}, \mathrm{OMe} ; \mathrm{R}^{2}=\mathrm{H}, \mathrm{Me}$<smiles></smiles>

67

Scheme 23. Syntheses of 1-hydroxyquinolyl- and 1-hydroxyisoquinolyl-1,2,3,4-tetrahydroisoquinolines.

dihydro-1H-naphth[1,2-e][1,3]oxazines revealed a significant dependence on the inductive effect of substituent $\mathrm{Y}\left(\sigma_{\mathrm{F}}\right)$, which was further evidence of the anomeric effect in the trans ring form. ${ }^{72}$ Systematic quantitative investigations of the ring-chain tautomeric equilibria of 2,4-diarylnaphth[2,1-e][1,3]oxazines demonstrated an analogous inductive influence on the ring ${ }^{\text {trans }}$-chain tautomeric equilibria. $^{73}$

For 1-alkyl-3-aryl-2,3-dihydro-1H-naphth[1,2-e][1,3]oxazines (75 $(\mathbf{a}-\mathbf{g})-\mathbf{7 9}(\mathbf{a}-\mathbf{g})$, Scheme 25), the influence of the alkyl substituent at position-1 on the ring-chain tautomeric equilibria could be described by the Meyer parameter, and that of the aryl substituent at position-3 by the Hammett-Brown parameter $\left(\sigma^{+}\right)$. The slopes of the Meyer parameter $V^{\mathrm{a}}$ for the trans and cis forms displayed a significant difference, which was explained in terms of an alkyl-substituent-controlled stereoelectronic effect in the trans ring form. ${ }^{74}$

The highly functionalized aminonaphthol $3 \mathbf{e}$ was converted into naphth $\left[1^{\prime}, 2^{\prime}: 5,6\right][1,3]$ oxazino[3,4-c][1,3]benzoxazines (80, Scheme 26), which were subjected to conformational analysis by NMR spectroscopy and accompanying molecular modelling. In particular, quantitative anisotropic ring-current effects of the aromatic moieties and steric substituent effects were employed to determine the stereochemistry of the naphthoxazinobenzoxazine derivatives. ${ }^{18}$

A novel method for the synthesis of 1-substituted 2,2dimethoxyethylamines (83) was introduced by $\mathrm{Hu}$ et al. The synthetic pathway involved the reaction of 3a with an aqueous solution of 2,2-dimethoxyacetaldehyde to yield $\mathbf{8 1}$, which was alkylated with Grignard reagents, followed by catalytic (Pd/C) hydrogenolysis of benzylamines 82 , to give the target products 83 directly (Scheme 26). ${ }^{75}$

Through the condensation of $\mathbf{3 n}, \mathbf{3 o}, \mathbf{6 i}$ and $\mathbf{6 j}$ with paraformaldehyde, 4-nitrobenzaldehyde, phosgene or 4-chlorophenyl isothiocyanate, naphthoxazine derivatives (84-91: Scheme 26 and 92-99: Scheme 27) were synthesized. The conformation of the oxazine ring moiety was found to depend on the hybridization of the carbon at position-3 or-2. The compounds that contained an $\mathrm{sp}^{3}$ carbon preferred a twisted-chair conformation, whereas the insertion of an $\mathrm{sp}^{2}$ carbon led to a nearly flat naphthoxazine ring moiety. ${ }^{20}$ 
<smiles>[R]NC([R])c1cc([X])c2ccccc2c1O</smiles><smiles>[X]c1ccc(O)c2ccccc12</smiles>

$\mathrm{X}=\mathrm{H}: 69 \mathrm{a}, 69 \mathrm{~b}$

$\mathrm{X}=$ OMe: $70 \mathrm{a}-\mathrm{c}$

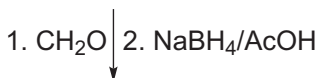<smiles>[X]c1cc(C([R])N([R])C)c(O)c2ccccc12</smiles>

$\mathrm{X}=\mathrm{H}: \mathbf{7 2 a}, \mathbf{7 2 b}$

$\mathrm{X}=\mathrm{OMe}: 73 \mathrm{a}-\mathrm{c}$

$$
\overbrace{\mathrm{R}^{2}}^{\mathrm{N}^{-R^{1}}}
$$

68

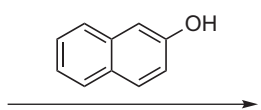<smiles>[R1]NC([R])c1c(O)ccc2ccccc12</smiles>

$\mathrm{R}^{1}-\mathrm{R}^{2}=-\left(\mathrm{CH}_{2}\right)_{3}-: \mathbf{a}$

71a-c $\mathrm{R}^{1}-\mathrm{R}^{2}=-\left(\mathrm{CH}_{2}\right)_{4}-: \mathbf{b}$<smiles>[R][R]#CCc1ccccc1CC</smiles><smiles>[R]C(c1c(O)ccc2ccccc12)N([R])C</smiles>

Scheme 24. Aza-Friedel-Crafts reactions between naphthol analogues and cyclic imines.<smiles>[X]c1cccc(C=O)c1</smiles>

3d,o-r MW $\downarrow \begin{aligned} & \mathrm{Et}_{3} \mathrm{~N} \\ & \mathrm{MeOH}\end{aligned}$<smiles>[X]c1ccc([C@@H]2NC([R])c3c(ccc4ccccc34)O2)cc1</smiles><smiles>[X]c1ccc(/C=N/C([R])c2c(O)ccc3ccccc23)cc1</smiles><smiles>[X]c1ccc(C2NC([R])c3c(ccc4ccccc34)O2)cc1</smiles>
$\mathrm{R}=\mathrm{Me}:$ $75 a-g B$ 75a-gA 76a-gA 77a-gA 78a-gA 79a-gA

$76 a-g B$

$77 a-g B$

$78 \mathrm{a}-\mathrm{gB}$

$\mathrm{R}=t$-Bu: $\quad 79 \mathrm{a}-\mathrm{gB}$

$\mathrm{X}=p-\mathrm{NO}_{2}: \mathbf{a} ; m-\mathrm{Cl}: \mathbf{b} ; p-\mathrm{Br}: \mathbf{c} ; p-\mathrm{Cl}: \mathbf{d} ; \mathrm{H}: \mathbf{e} ; p-\mathrm{Me}: \mathbf{f} ; p-\mathrm{OMe}: \mathbf{g}$

$75 a-g C$ 76a-gC $77 \mathrm{a}-\mathrm{gC}$ $78 \mathrm{a}-\mathrm{gC}$ 79a-gC

Scheme 25. Syntheses of 1-alkyl-3-arylnaphth[1,2-e][1,3]oxazines.

1-Aryl- $N, N$-dimethyl-1H-naphth[1,2-e][1,3]oxazine-3-amine derivatives (101, Scheme 28 ) were synthesized in the reactions of 2 naphthol, aromatic aldehydes and $N, N, N^{\prime}, N^{\prime}$-tetramethylguanidine through the intermediate $\mathbf{1 0 0}$, under microwave irradiation. ${ }^{76}$

The condensations of $N$-heteroaryl aminonaphthols (30) with oxalyl chloride led to the formation of 1,2-disubstituted naphth[1,2- $f]$ [1,4]oxazepine-3,4-diones (102, Scheme 29) ${ }^{39}$

The intramolecular cyclization of $\mathbf{1 0 3}$ by use of the Vilsmeier reagent (DMF 12 equiv, $\mathrm{POCl}_{3} 8$ equiv) afforded dialdehydes 104; Perumal et al. extended the reaction to amidoalkylnaphthols $\mathbf{1 0 5}$, leading to 106 (Scheme 30). ${ }^{77}$

A series of trans-1,3-diaryl-1H-naphth[1,2-e][1,3]oxazine2(3H)-carbonyl chlorides (109) and 1-aryl-2-benzyl-1H-naphth [1,2-e][1,3]oxazin-3-ones (110) were prepared by the chemoselective reaction of 1,3-diaryl-2,3-dihydro-1H-naphth[1,2-e][1,3] oxazines (108) and triphosgene induced by different low-valent titanium systems, while the transformation of $\mathbf{1 0 8}$ with triethyl orthoformate in the same catalytic system led to the formation of trans-1,3-diaryl-1H-naphth[1,2-e][1,3]oxazine-2(3H)-carbaldehydes (111: Scheme 31). ${ }^{78}$

The benzyloxycarbonyl-protected intermediates $(\mathbf{1 1 2} \mathbf{a}-\mathbf{f})$ in the syntheses of naphth[1,2-e][1,3]oxazino[3,2-c]quinazolin-13-one derivatives (113a-f, Scheme 32), formed through the reactions of substituted aminonaphthol derivatives (3) with benzyl $\mathrm{N}$-(2-formylphenyl)carbamate, existed not only as the expected trans ring form $\mathbf{B}$ and chain form $\mathbf{A}^{\mathbf{1}}$, but also as the rearranged chain form $\mathbf{A}^{\mathbf{2}}$ as a new tautomer in DMSO at room temperature. The quantity of $\mathbf{A}^{\mathbf{2}}$ in the tautomeric mixture varied with time. Compounds 112a-f were transformed into naphth[1,2-e][1,3]oxazino[3,2-c] quinazolin-13-one derivatives (113a-f) by solvent-free heating with MeONa. ${ }^{79}$

Itoh et al. reported the synthesis of novel sulphonamide derivatives 114a-i and $\mathbf{1 1 5}$ from non-racemic aminonaphthol 3a and various sulphonyl chlorides (Scheme 33). ${ }^{80}$ 
<smiles>[R]C1Oc2cccc3cccc(c23)C1c1cccc2ccccc12</smiles>

80<smiles>COC(OC)C1NC(c2ccccc2)c2c(ccc3ccccc23)O1</smiles>

$(\mathrm{MeO})_{2} \mathrm{CHCHO}$

$\mathrm{R}^{4} \mathrm{MgBr}, \mathrm{THF}, \mathrm{rt}$<smiles>[R]C(NC(c1ccccc1)c1c(O)ccc2ccccc12)C([R])OC</smiles>

82

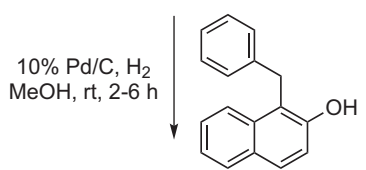<smiles>[R]C(N)C(OC)OC</smiles>

83

$\mathrm{R}^{1}=1-\mathrm{Nph}: \mathbf{8 4} ; \mathbf{2 - N p h :} \mathbf{8 5}$

$$
\begin{aligned}
& \mathrm{R}^{1}=2-\mathrm{OH}-\mathrm{C}_{6} \mathrm{H}_{4}: 3 \mathbf{3 e} ; \mathrm{Ph}: 3 \mathbf{a} \\
& \text { 1-Nph: } 3 \mathbf{m}, 2-\mathrm{Nph}: 3 \mathbf{n}
\end{aligned}
$$<smiles>[R]C1NCOc2ccc3ccccc3c21</smiles>

$\mathrm{R}^{1}=1-\mathrm{Nph}: \mathbf{8 6} ; \mathbf{2 - N p h :} \mathbf{8 7}$<smiles>CCO</smiles><smiles>[R]C(NC(=S)Nc1ccc(Cl)cc1)c1c(O)ccc2ccccc12</smiles><smiles>[R]C1NC(=Nc2ccc(Cl)cc2)Oc2ccc3ccccc3c21</smiles>

$\mathrm{R}^{1}=$ 1-Nph: 88; 2-Nph: 89

$\mathrm{R}^{1}=$ 1-Nph: 90 ; 2-Nph: 91

$$
\begin{gathered}
\mathrm{R}^{2}=\mathrm{H}, \mathrm{Ph},=\mathrm{O} \\
\mathrm{R}^{3}=\mathrm{H}, \mathrm{Ph}
\end{gathered}
$$

$\mathrm{R}^{4}=\mathrm{Me}, \mathrm{Pr}, \mathrm{Me}\left(\mathrm{CH}_{2}\right)_{4}, 3-\left[(1,3)\right.$-dioxan-2-yl]-1-propyl, cyclopropyl, cyclopentyl, $\mathrm{Ph}, 2-\mathrm{Me}-\mathrm{C}_{6} \mathrm{H}_{4}$, 3-Me- $\mathrm{C}_{6} \mathrm{H}_{4}, 4-\mathrm{Me}-\mathrm{C}_{6} \mathrm{H}_{4}, 3,4-\mathrm{di}-\mathrm{Me}-\mathrm{C}_{6} \mathrm{H}_{3}, 2-\mathrm{OMe}-\mathrm{C}_{6} \mathrm{H}_{4}, 3-\mathrm{OMe}-\mathrm{C}_{6} \mathrm{H}_{4}, 4-\mathrm{OMe}-\mathrm{C}_{6} \mathrm{H}_{4}, 3,4-$ di-OMe- ${ }_{6} \mathrm{H}_{3}$

Scheme 26. Transformations of aminonaphthol derivatives 3.<smiles>[R]C1NCOc2c1ccc1ccccc21</smiles>

$\mathrm{R}^{1}=$ 1-Nph: 92; 2-Nph: 93<smiles>[R]C(N)c1ccc2ccccc2c1O</smiles>

$\mathrm{R}^{1}=1-\mathrm{Nph}: \mathbf{6} \mathbf{i}, 2-\mathrm{Nph}: \mathbf{6 j}$<smiles>[R]C1NC(=O)Oc2c1ccc1ccccc21</smiles>

$\mathrm{R}^{1}=$ 1-Nph: 94; 2-Nph: 95<smiles>[R]C(NC(=S)Nc1ccc(Cl)cc1)c1ccc2ccccc2c1O</smiles>

$\mathrm{R}^{1}=$ 1-Nph: 96; 2-Nph: 97<smiles>[R]C1N/C(=N\c2ccc(Cl)cc2)Oc2c1ccc1ccccc21</smiles>

$\mathrm{R}^{1}=1-\mathrm{Nph}:$ 98; 2-Nph: 99

Scheme 27. Transformations of aminonaphthol derivatives 6.

Intermediates 8, isolated from the reactions of 6-bromo-2naphthol (7) and aromatic aldehydes in the presence of ammonia, were in turn reacted with 4-nitroaniline to obtain 116 as novel mordant and disperse azo-azoimine dyes (Scheme 34). ${ }^{81}$

The cyclization of $\mathbf{6 5 a} \mathbf{a}, \mathbf{b}$ and $\mathbf{6 4 a}, \mathbf{b}$ with formaldehyde, phosgene, $p$-nitrobenzaldehyde or $p$-chlorophenyl isothiocyanate resulted in 8 -substituted 10,11-dihydro-8H,15bH-naphth[2,1-e]
[1,3] oxazino[4,3-a][1,3]isoquinolines (117a,b-121a,b, Scheme 35) and 10,11-dihydro-8H,15bH-naphth[1,2-e][1,3]oxazino[4,3-a][1,3] isoquinolines (122a,b-126a,b, Scheme 36). Conformational analysis of the piperidine and 1,3-oxazine moieties of these heterocycles by NMR spectroscopy and an accompanying theoretical ab initio study revealed that these two conformationally flexible six-membered ring-moieties prefer twisted half-chair conformers. ${ }^{82,83}$ 
<smiles>Oc1ccc2ccccc2c1</smiles>

1

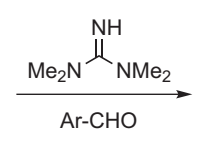<smiles>CN(C)C(=NC(Br)c1c(O)ccc2ccccc12)N(C)C</smiles>

100<smiles>CN(C)C1=NC(Br)c2c(ccc3ccccc23)O1</smiles>

101

$\mathrm{Ar}=\mathrm{Ph}, 3-\mathrm{Me}-\mathrm{C}_{6} \mathrm{H}_{4}, 4-\mathrm{OMe}-\mathrm{C}_{6} \mathrm{H}_{4}, 4-\mathrm{Cl}-\mathrm{C}_{6} \mathrm{H}_{4}, 4-\mathrm{NO}_{2}-\mathrm{C}_{6} \mathrm{H}_{4}, 2-\mathrm{Br}_{-}-\mathrm{C}_{6} \mathrm{H}_{4}$, 2-thienyl, 2-furyl

Scheme 28. Syntheses of 1-aryl- $N, N$-dimethylnaphth[1,2-e][1,3]oxazine-3-amines.<smiles>[X]c1ccc(C(Nc2cccnc2)c2c(O)ccc3ccccc23)cc1</smiles>

30
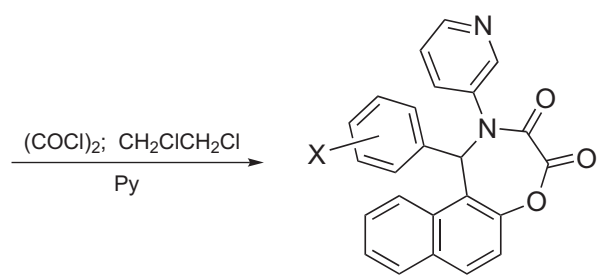

102
$\mathrm{X}=\mathrm{H}, 4-\mathrm{Cl}$, 4-F, 4-Br, 4-OMe, 4-Me, 2-Cl, 3-Br, 2-OMe

Scheme 29. Synthesis of 1,2-disubstituted naphth[1,2-f][1,4]oxazepine-3,4-diones. from that time, which are mostly restricted to the technical and/or substrate modifications in the test reactions.

Chan et al. successfully applied 21a and $\mathbf{2 1 b}$ as highly efficient ligands for asymmetric catalytic phenyl transfer to aromatic aldehydes. By means of this reaction, a variety of chiral diarylmethanols were prepared with high (up to 99\%) ee values and in high chemical yields. $^{32}$ Dahmen and Lormann highlighted the value of arylboranes as precursors for arylzinc reagents in asymmetric catalysis. On the application of 21a, the desired diarylmethanols were isolated with high (up to $98 \%$ ) ee values. ${ }^{86}$

In tests of the enantiomeric induction of $21 \mathbf{c}-\mathbf{e}, \mathbf{2 2 c}$ and $22 \mathbf{e}$ in the addition of diethylzinc to arylaldehydes, comparison of the results with the literature data demonstrated that the bulkier naph-

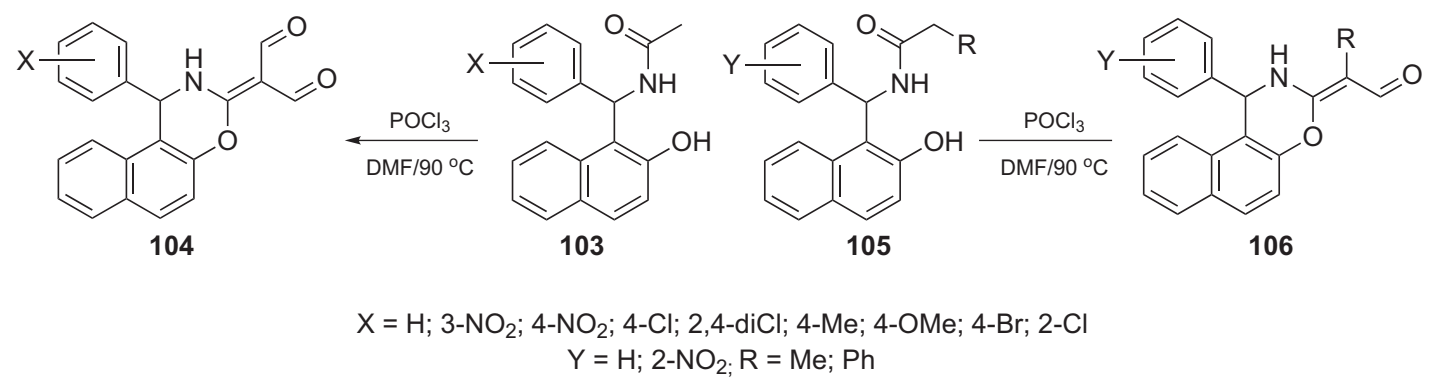

Scheme 30. Transformations of amidoalkylnaphthols 103 and 104 with Vilsmeier reagent.

The N-substitution of 1-(1,2,3,4-tetrahydroisoquinolin-1-yl) naphthalen-2-ol $(\mathbf{6 4 a})$ on reaction with alkyl halides yielded $127 \mathbf{a}-\mathbf{e}$. The separation of the enantiomers of $127 \mathbf{a}-\mathbf{d}$ was achieved by using dibenzoyl L-tartaric acid, while for 127e the semipreparative chiral HPLC method proved successful (Scheme 36). ${ }^{67}$

Unexpected reactions between 1 - $\alpha$-aminobenzyl-2-naphthol (3a) or 1-aminomethyl-2-naphthol (129) and 6,7-dimethoxy-3,4dihydroisoquinoline $\left(\mathbf{6 3} ; \mathrm{R}^{1}=\mathrm{R}^{2}=\mathrm{H}\right.$; Table 3$)$ furnished naphth [1,2-e][1,3]oxazino[2,3-a]isoquinolines (128 and 130, Scheme 37). The reaction conditions involved classical heating at $80^{\circ} \mathrm{C}$ in $\mathrm{MeCN}$ for $22 \mathrm{~h}(i)$, or the use of microwave conditions $\left(100^{\circ} \mathrm{C}, i i\right)$, which allowed a decrease of the reaction time to $90 \mathrm{~min}$ and resulted in somewhat higher yields. ${ }^{84}$

Chiral calix[4]arenes 132-135 were synthesized from 131 and chiral aminonaphthols by Sirit et al. (Scheme 38). ${ }^{85}$

\subsection{Applications in enantioselective transformations}

The use of non-racemic aminonaphthol derivatives as chiral ligands is one of the most important areas of application of these types of compounds. The enantiopure aminonaphthols proved to be good-to-excellent chiral catalysts in the enantioselective addition of diethylzinc to benzaldehyde (Noyori reaction). The results of their enantiomeric inductions have been fully reviewed up to $2004 .^{6}$ The present review covers the results that have appeared thylethyl group on the $N$ atom did not cause significantly higher enantioselectivity in the enantioselective alkylation of arylaldehydes. ${ }^{6}$ Furthermore, the tertiary aminonaphthols did not improve the ee values significantly. Concerning the influence of the aryl substituents on the addition of diethylzinc to arylaldehydes, higher ee values were achieved in all cases for the $p$-OMe substituent than for $p$-Me or $\mathrm{H}$. All the reactions were substantially accelerated by using microwave irradiation, and temperature increase (depending on the structure of the chiral ligands) led to the same ee values or to the formation of the racemic 1-aryl-propanol. ${ }^{33} \mathrm{Li}$ et al. tested the catalytic behaviour of ligands $21 \mathbf{f}-\mathbf{q}$ and $\mathbf{2 2 f}-\mathbf{q}$ in the asymmetric phenyl transfer to aromatic aldehydes, and found that ortho electron-donating substituents on the aldehyde moiety of the ligands promoted higher enantioselectivities, while strongly electron-attracting groups were unfavourable to the ee values. ${ }^{34}$

The same model reaction was used to test the enantioselectivity of 127a. In order to improve the moderate ee values (up to $70 \%$ ), 65 127b-e were synthesised and examined. ${ }^{67}$ It emerged that modifications at the $N$ atom reduced the efficiency of these ligands, whereas modifications at position-3 of the 1,2,3,4tetrahydroisoquinoline ring and position-3 of the naphthyl ring $((1 S, 3 R)-640-t)$ improved (ee up to $96 \%)$ the enantioselectivity. ${ }^{67}$

Another model reaction in which the enantioinductions of nonracemic sulphonamide derivatives $\mathbf{1 1 4 a}-\mathbf{i}$ and $\mathbf{1 1 5}$ were tested was the hetero-Diels-Alder reaction of ethyl glyoxylate with 
<smiles>[R]C1NC([R])c2c(ccc3ccccc23)O1</smiles>

108B<smiles>[R]C(N)c1c(O)ccc2ccccc12</smiles>

107<smiles>C1=CC=C1</smiles><smiles>[R]C=NC([R])c1c(O)ccc2ccccc12</smiles>

108A

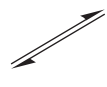<smiles>[R]C1NC([R])c2c(ccc3ccccc23)O1</smiles><smiles>[R]C1Oc2ccc3ccccc3c2C([R])N1C(=O)Cl</smiles>

109<smiles>CCOC(=O)OC(Cl)(Cl)Cl</smiles>

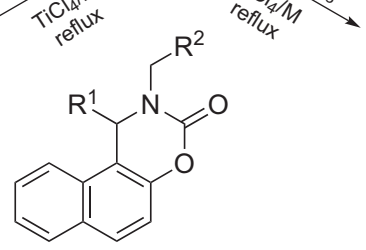

110<smiles>[R]C1c2c(ccc3ccccc23)O[C@@H](C)N1C(C)=O</smiles>

111

$\mathrm{R}^{1}=4-\mathrm{Br}-\mathrm{C}_{6} \mathrm{H}_{4}, \mathrm{Ph}, 4-\mathrm{Cl}-\mathrm{C}_{6} \mathrm{H}_{4}, 4-\mathrm{Me}-\mathrm{C}_{6} \mathrm{H}_{4}, 4-\mathrm{F}-\mathrm{C}_{6} \mathrm{H}_{4}$ $\mathrm{R}^{2}=4-\mathrm{Br}-\mathrm{C}_{6} \mathrm{H}_{4}, \mathrm{Ph}, 4-\mathrm{Cl}-\mathrm{C}_{6} \mathrm{H}_{4}, 4-\mathrm{F}-\mathrm{C}_{6} \mathrm{H}_{4}, 3,4-$ di-Cl- $\mathrm{C}_{6} \mathrm{H}_{3}, 4-\mathrm{Me}_{6}-\mathrm{C}_{6} \mathrm{H}_{4}$, 2-thienyl

Scheme 31. Syntheses of 1,3-diarylnaphth[1,2-e][1,3]oxazines.<smiles>[R]C(N)c1c(O)ccc2ccccc12</smiles>

3<smiles>[R]C(N=Cc1ccccc1NC(=O)OCc1ccccc1)c1ccc([14CH3])cc1O</smiles>
CbzHN<smiles>[R]C1([R])NC(c2ccccc2NC(=O)OC)Oc2ccc3ccccc3c21</smiles>

112a-fB
4
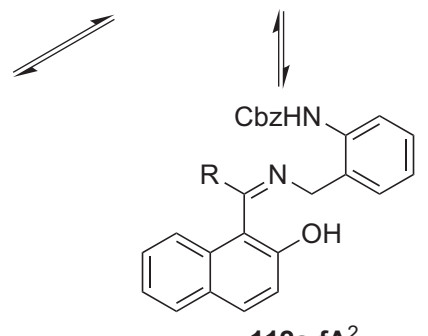

$112 a-f A^{2}$

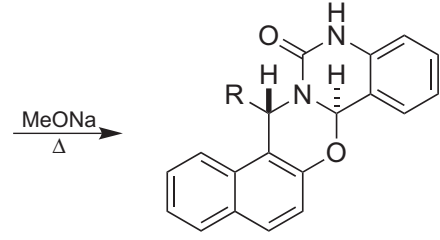

113a-f

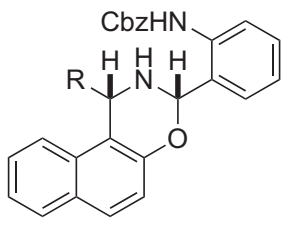

112a-fC

$\mathrm{R}=\mathrm{H}: \mathbf{a} ; 4-\mathrm{Cl}-\mathrm{C}_{6} \mathrm{H}_{4}: \mathbf{b} ; \mathrm{Ph}: \mathbf{c} ; 4-\mathrm{OMe}-\mathrm{C}_{6} \mathrm{H}_{4}: \mathbf{d} ; 1-\mathrm{Nph}: \mathbf{e} ; 2-\mathrm{Nph}: \mathbf{f}$

Scheme 32. Syntheses of naphth[1,2-e][1,3]oxazino[3,2-c]quinazolin-13-ones.<smiles>[R]C(C)(C)S(=O)(=O)Cl</smiles>

3a<smiles>[R]S(=O)(=O)N[C@H](c1ccccc1)c1c(O)ccc2ccccc12</smiles>

114a-i<smiles>COc1ccc2ccccc2c1[C@H](NS(=O)(=O)c1cc(C(F)(F)F)cc(C(F)(F)F)c1)c1ccccc1</smiles>

115

$\mathrm{R}=\mathrm{CF}_{3}: \mathbf{a}, \mathrm{C}_{4} \mathrm{~F}_{9}: \mathbf{b}, \mathrm{Ph}: \mathbf{c}, 4-\mathrm{Me}-\mathrm{C}_{6} \mathrm{H}_{4}: \mathbf{d}, 4-\mathrm{NO}_{2}-\mathrm{C}_{6} \mathrm{H}_{4}: \mathbf{e}$,

2,4-di- $\mathrm{NO}_{2}-\mathrm{C}_{6} \mathrm{H}_{3}: \mathbf{f}, 3,6-$ di- $^{-} \mathrm{CF}_{3}-\mathrm{C}_{6} \mathrm{H}_{3}: \mathbf{g}, 1-\mathrm{Nph}: \mathbf{h}, 2-\mathrm{Nph}: \mathbf{i}$

Scheme 33. Syntheses of aminonaphthols containing a sulphonamide moiety. 


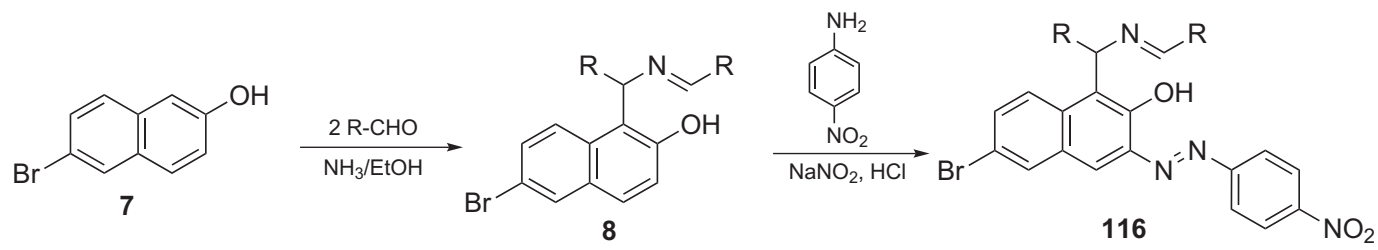

$\mathrm{R}=\mathrm{Ph}, 2-\mathrm{OH}-\mathrm{C}_{6} \mathrm{H}_{4}, 2-\mathrm{NO}_{2}-\mathrm{C}_{6} \mathrm{H}_{4}, 3-\mathrm{NO}_{2}-\mathrm{C}_{6} \mathrm{H}_{4}, 2$ furyl, 4-OH- $\mathrm{C}_{6} \mathrm{H}_{4}, 4-\mathrm{NMe}_{2}-\mathrm{C}_{6} \mathrm{H}_{4}, 2-\mathrm{Cl}-\mathrm{C}_{6} \mathrm{H}_{4}, 3-\mathrm{Br}-\mathrm{C}_{6} \mathrm{H}_{4}$

Scheme 34. Syntheses of azo-azoimine dyes $\mathbf{1 1 6}$.<smiles>[R]c1cc2c(cc1[R])C1c3ccc4ccccc4c3OCN1CC2</smiles>

$\mathrm{R}=\mathrm{H}: 117 \mathrm{a}$ $\mathrm{R}=\mathrm{OMe}: 117 \mathrm{~b}$

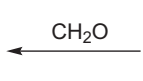<smiles>[R]c1cc2c(cc1[R])C(c1ccc3ccccc3c1O)NCC2</smiles>

$\mathrm{R}=\mathrm{H}: 65 \mathrm{a}$ $\mathrm{R}=\mathrm{OMe}: \mathbf{6 5 b}$

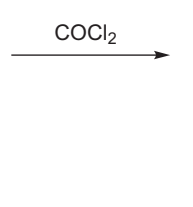<smiles>[R]c1cc2c(cc1[R])C1c3ccc4ccccc4c3OC(=O)N1CC2</smiles>

$\mathrm{R}=\mathrm{H}: 118 \mathrm{a}$

$\mathrm{R}=\mathrm{OMe}: \mathbf{1 1 8 b}$

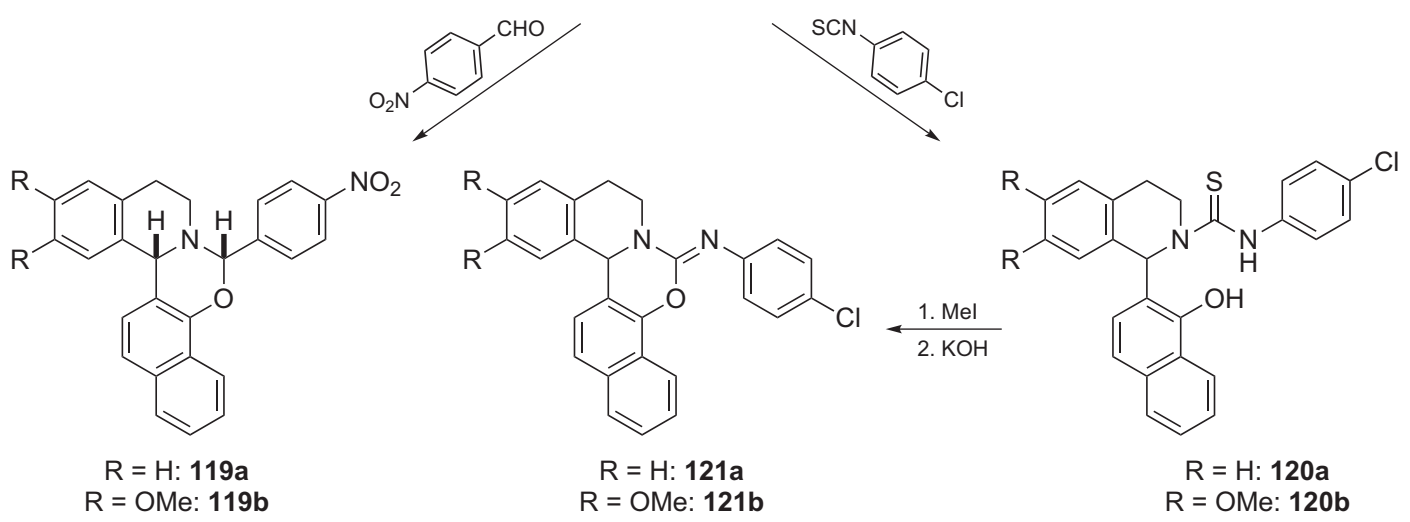

Scheme 35. Transformations of 1-(1-hydroxynaphthyl)-1,2,3,4-tetrahydroisoquinolines.

Danishefsky's dienes. Most of the ligands gave the desired 2substituted 2,3-dihydropyran-4-ones with moderate ees (50-55\%), although with somewhat higher enantioinduction (ee $=70-74 \%$ ) on the use of $\mathbf{1 1 5}$ as chiral organocatalyst. ${ }^{80}$

The applications of non-racemic aminonaphthols were recently extended to their use for the synthesis of other chiral compounds, e.g., chiral auxiliaries. These investigations mostly start from the non-racemic Betti base (3a). An efficient kinetic method for the resolution of racemic 3a with $\mathrm{L}-(+)$-tartaric acid in acetone, based on a novel N,O-deketalization, was developed by $\mathrm{Hu}$ et al. ${ }^{87}$

Hutton et al. succeeded in achieving the stereoselective asymmetric synthesis of 137 via 136 (Scheme 39) through a novel chirality-transfer process, yielding compounds exclusively stereogenic at the boron. 88

By the reaction of (S)-3a and dialdehydes, diastereopure $\alpha$-benzotriazolyl (Bt) 1-azacycloalka[2,1-b][1,3]oxazines 138a-c were prepared, ${ }^{89,90}$ from which the enantioselective syntheses of 139a-c and 141 (via 140) were performed (Scheme 40). ${ }^{90}$

A series of enantiopure piperidines $(\mathbf{1 4 4})^{87}$ or $(2 S, 6 R)$-disubstituted piperidines (147) ${ }^{90}$ were prepared by Hu et al. via intermediates $138 a-c, 142$ and 143 , or 145 and 146 starting from (S)-3a as an excellent chiral auxiliary (Scheme 41 ). The process was extended to the syntheses of non-racemic 2,5-disubstituted pyrrolidines (150) through 148 and 149, which proved to be good precursors for (-)-cocaine and (-)-ferruginine (Scheme 41). ${ }^{91}$
A general method for the synthesis of enantiopure 2-alkene- or 2-alkyne-substituted piperidines (152) was devised by starting from 138b (Scheme 42). ${ }^{92,93}$ It is interesting to note that a novel base-catalysed N-debenzylation of $\mathbf{1 4 9}$ and $\mathbf{1 5 1}$ was applied instead of hydrogenolysis for the synthesis of $\mathbf{1 5 0}$ and $\mathbf{1 5 2}$ in order to avoid saturation of the alkene or alkyne side chain.

A simple and efficient approach to enantiopure $\alpha$-aminophosphonic acids $(\mathbf{1 5 5 a}-\mathbf{c})$, based on the reactions of chiral benzylidenes $(\mathbf{1 5 3} \mathbf{a}-\mathbf{c})$ derived from the enantiomers of $\mathbf{3 a}$ with trialkyl phosphites in the presence of TFA (Scheme 43), through the intermediates $\mathbf{1 5 4 a}-\mathbf{c}$ was described by Alfonsov et al. ${ }^{94,95}$

A series of new chiral phosphoramidate ligands (160; Scheme 44) were synthesized from the $O$-protected non-racemic aminonaphthol derivatives 159 and BINOL, starting from the enantiopure aminonaphthol 156, via 157 and $\mathbf{1 5 8}$. The ligands were tested in the palladium-catalysed enantioselective hydrosilylation of styrene derivatives. The ligands with the $(S, R, R)$ configuration were found to be effective catalysts (ees up to $97 \%$ ) of these model reactions. ${ }^{96}$

\subsection{Miscellaneous applications}

The high number of that papers have recently appeared with special applications indicate that the uses of these compounds are not restricted solely to enantioselective transformations. 


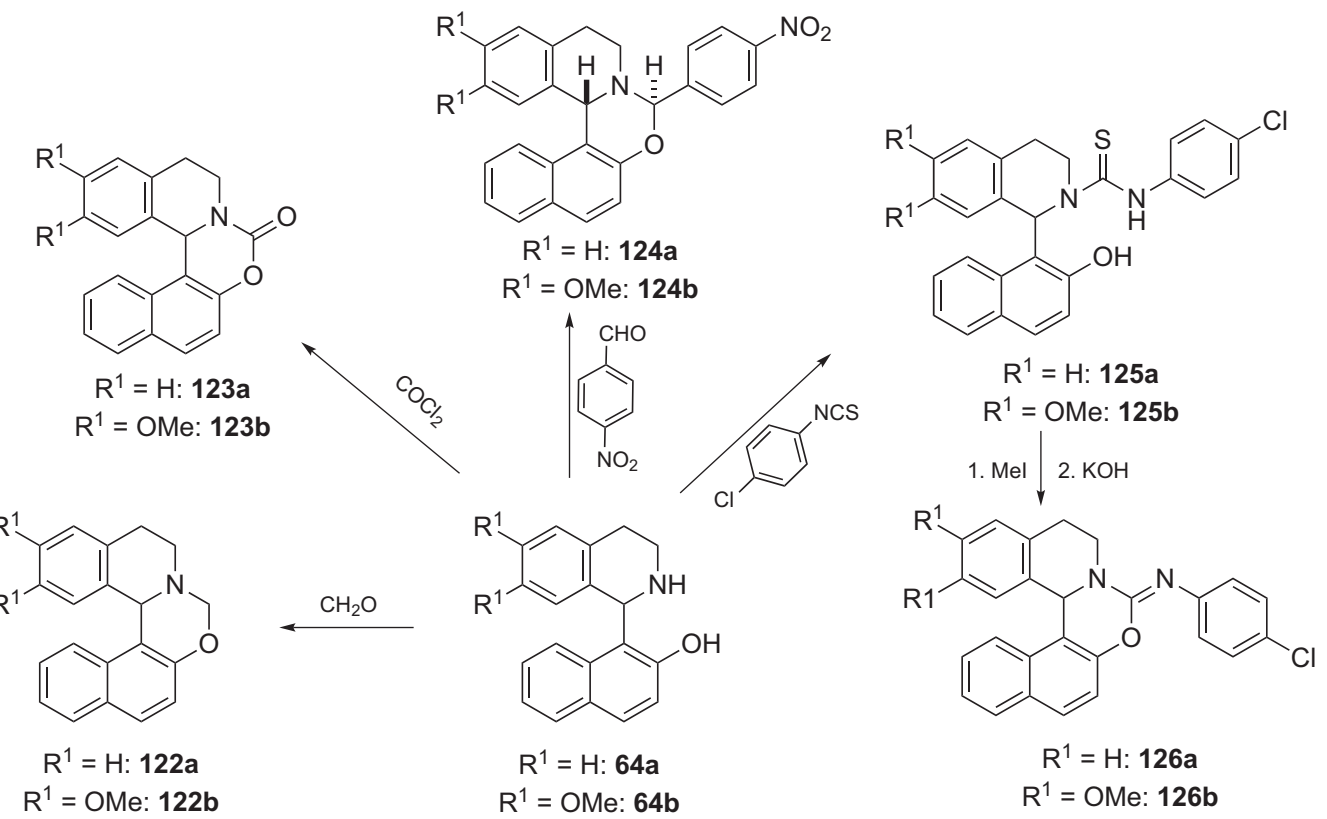

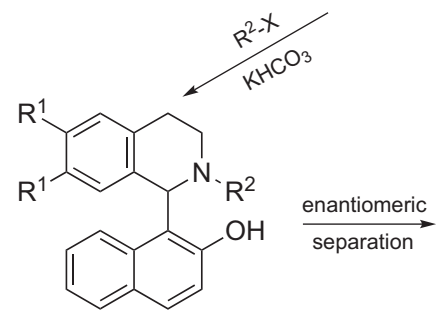

127a-e<smiles>[R]C([R])c1cc2c(cc1-c1c(O)ccc3ccccc13)C([R])CCN2</smiles>

(+)-127a-e<smiles>[R]c1cc2c(cc1[R])C(c1c(O)ccc3ccccc13)=NCC2</smiles>

(-)-127a-e

$\mathrm{R}^{1}=\mathrm{H} ; \mathrm{R}^{2}=\mathrm{Me}: \mathbf{a}$; Et: b; Pr: c; Allyl: d; Bn: e

Scheme 36. Transformations of 1-(2-hydroxynaphthyl)-1,2,3,4-tetrahydroisoquinolines.<smiles>COc1cc2c(cc1OC)C1CCNC(c3ccccc3)(N2)c2c(ccc3ccccc23)O1</smiles>

128

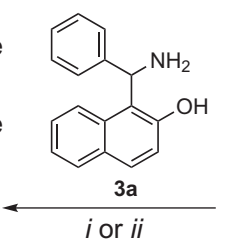<smiles>COc1cc2c(cc1OC)CCN=C2</smiles>

63

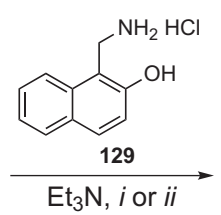

$\mathrm{Et}_{3} \mathrm{~N}, i$ or $i$

(a)<smiles>COc1cc2c(cc1OC)C1Oc3ccc4ccccc4c3CN1CC2</smiles>

130

Scheme 37. Syntheses of naphth[1,2-e][1,3]oxazino[2,3-a]isoquinolines.

The aminonaphthol analogues 13 and $21 \mathrm{f}$ have been used as ligands in the palladium-catalysed Mizoroki-Heck reaction. Interestingly, high turnover numbers were observed in the reactions with aryl bromides and iodides, whereas aryl chlorides were inert. 97

When the inter- or intramolecular $\mathrm{N} \cdots \mathrm{H}-\mathrm{O}$ or $\mathrm{N}-\mathrm{H} \cdots \mathrm{O} \mathrm{H}-$ bonding in 3a, 3d and $\mathbf{6 a}$ and their derivatives was examined, it was found that the strength of the intramolecular $\mathrm{H}$ bond depends on the steric and electronic effects of the substituents. ${ }^{98}$

In recent studies, 1 -( $\alpha$-aminoarylmethyl)-2-naphthol, $1-\alpha$-aminoalkyl-2-naphthol and 2-( $\alpha$-aminoarylmethyl)-1-naphthol enantiomers were separated on different chiral HPLC columns. Quantitative investigations were also made of the relationships between the HPLC parameters and the substituents on the aminonaphthols. ${ }^{99-104}$ The structures of 21c and 21e contain two stereogenic centres, and the enantioseparation of such racemic and non-racemic aminonaphthols was achieved on an AmyCoat ${ }^{\mathrm{TM}}$ or CelluCoat ${ }^{\mathrm{TM}}$ HPLC stationary phase. ${ }^{105,106}$

Naphthoxazinobenzoxazines $\mathbf{8 0}$ and their derivatives (pyrrolonaphthoxazinones) were studied by using mass spectrometry in order to establish the effects of the regioisomers and substituents on the fragmentation. ${ }^{107}$

\subsection{Biological activity}

Naphthoxazinone derivatives have received considerable attention in view of the interesting pharmacological properties associated with this heterocyclic scaffold. ${ }^{108-110}$ It has been reported that they act as antibacterial agents, ${ }^{111}$ while a benzoxazinone derivative was approved by the FDA as a non-nucleoside reverse transcriptase inhibitor in 1998, and is currently in clinical use for the treatment of AIDS. ${ }^{112}$ 


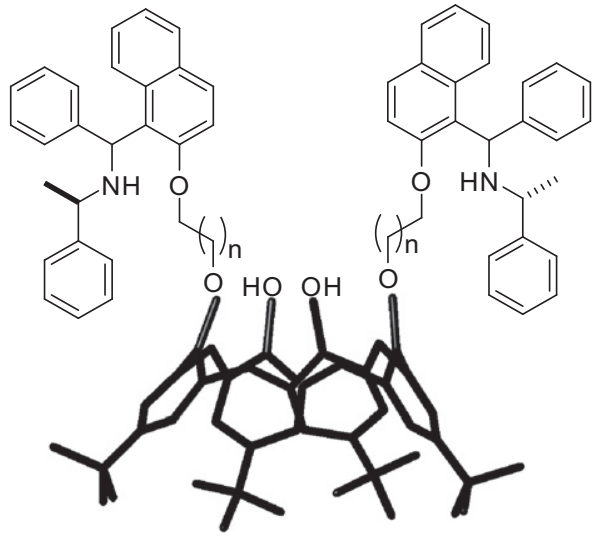

$\mathrm{n}=1,2,3: 132$

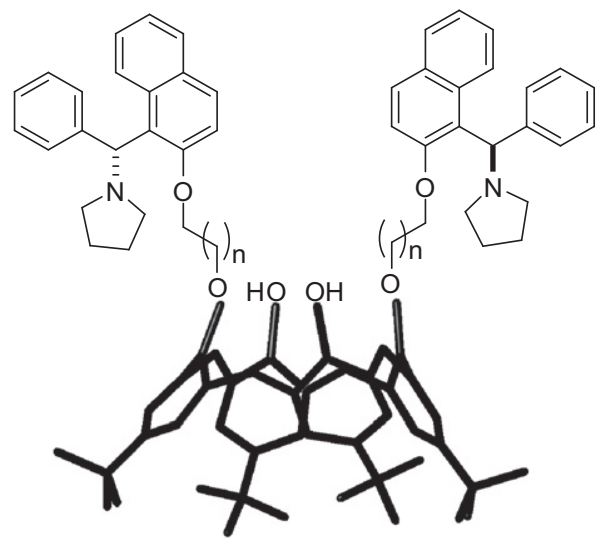

$\mathrm{n}=1,2: 134$
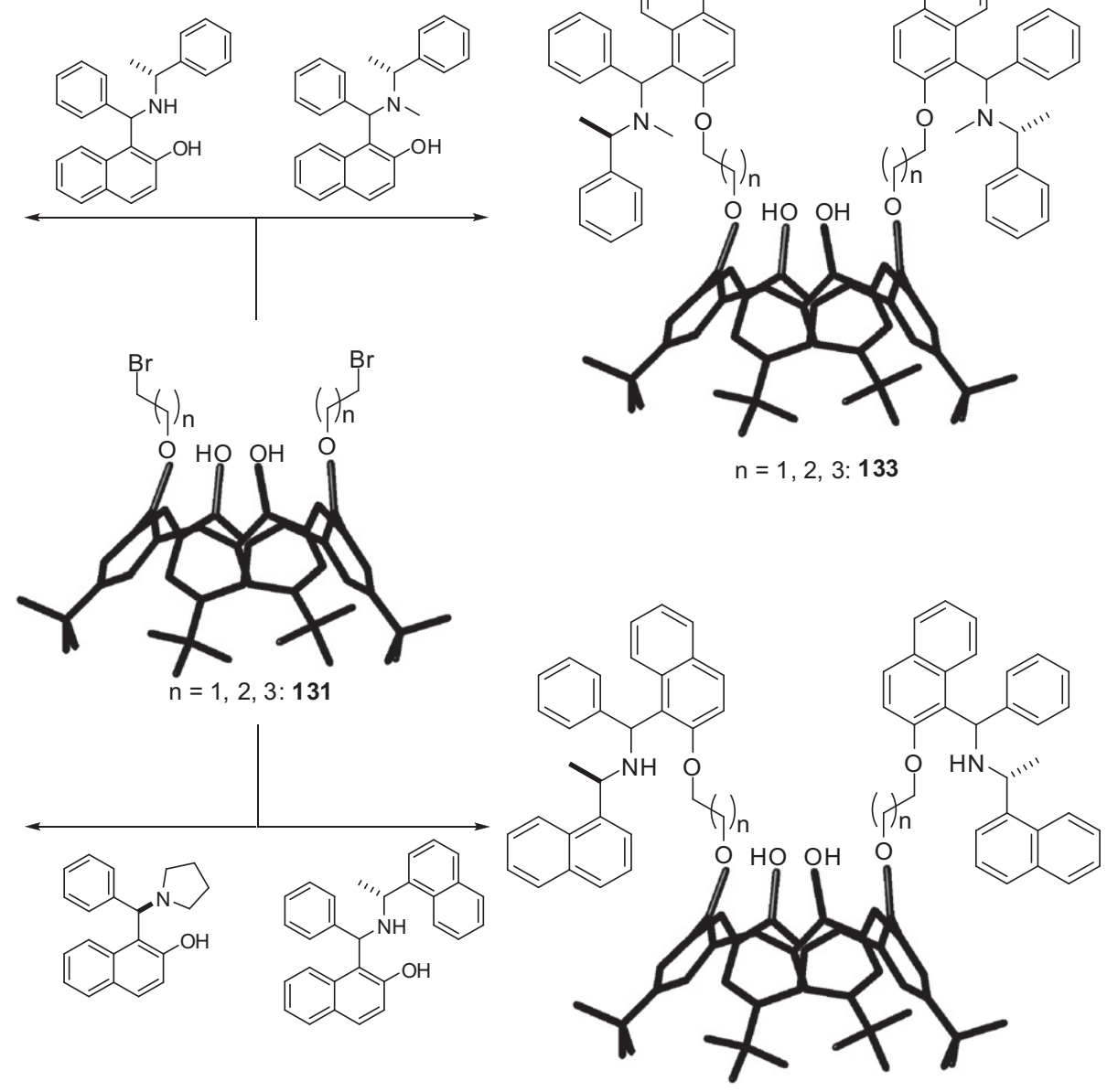

$n=2: 135$

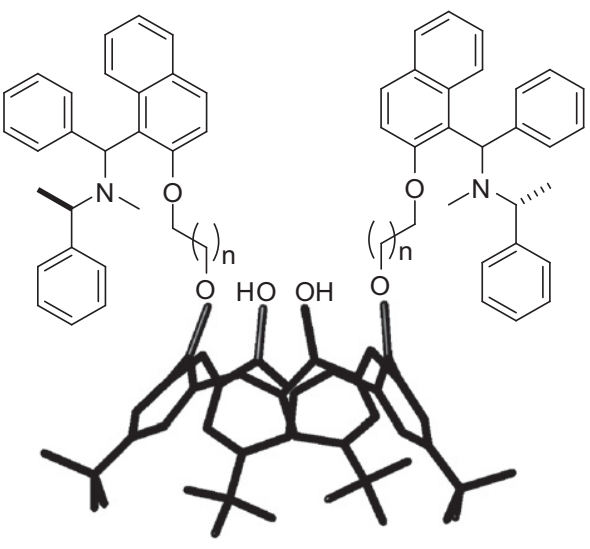

$\mathrm{n}=1,2,3: 133$

Scheme 38. Syntheses of chiral calix[4]arenes 132-135.<smiles>N[C@H](c1ccccc1)c1c(O)ccc2ccccc12</smiles>

(S)-3a

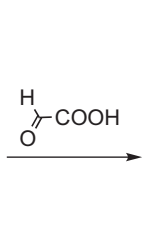

Many functionalized quinolines and isoquinolines are widely employed as antimalarial, anti-asthmatic or anti-inflammatory agents or as antibacterial, antihypertensive and tyrosine kinase PDGF-RTK-inhibiting agents. In an integrated, virtual database screening, their analogues containing a hydroxyl group, such as 7[anilino(phenyl)methyl]-2-methyl-8-quinolinol (50; $\mathrm{X}=\mathrm{Me}, \mathrm{Y}=\mathrm{H}$, $\mathrm{R}=\mathrm{Ph}$; Scheme 17), were found to be a promising new class of nonpeptide inhibitors of the MDM2-p53 interaction. ${ }^{14}$

Recent, biochemical and X-ray crystallographic studies after a virtual screening confirmed that hydroxyquinolines $(\mathbf{5 0} ; \mathrm{X}=\mathrm{H}$, $\mathrm{Y}=\mathrm{H}, 2-\mathrm{Me}$, 4-Me, 2-OMe, 4-OMe, 2-OEt, 4-OEt, 2-Cl, 4-Cl, R=2-Py; Scheme 17) were actually covalent inhibitors of MIF tautomerase. ${ }^{15}$ Another virtual screening demonstrated that $7-[(3-$ fluorophenylamino)(pyridin-2-yl)methyl]-8-quinolinol $(\mathbf{5 0} ; \mathrm{X}=\mathrm{H}$,
$\mathrm{Y}=3-\mathrm{F}, \mathrm{R}=2-\mathrm{Py}$; Scheme 17) was an MIF-CD74 inhibitor at low micromolar concentrations, acting as a weak tautomerase inhibitor. ${ }^{16}$

The in vitro efficacy of compounds $\mathbf{5 2}$ against Escherichia coli, Vibria cholerae, Achromobacter hydrophilis, Proteus mirabilis, Klebsiella pneumoniae, Salmonella typhii, Plesiomonas schigellaides, Proteus vulgaris, Citrobacter and Citrobacter ovis revealed that derivatives containing a 2-pyrimidinyl group on the sulphonamide moiety were the most effective. ${ }^{61}$

When compounds 59 and 60 were screened for their fungicidal activity against Pyricularia oryzae (Cav) and for their antibacterial activity against E. coli and Staphylococcus aureus by the usual methods, ${ }^{12}$ almost all of them exhibited promising antifungal and antibacterial activities. Introduction of a halogen atom at C -5 of either the thiazole or the oxazole moiety augmented the activity. 


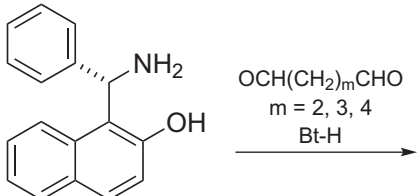

(S)-3a<smiles>CC1CC2Oc3ccc4ccccc4c3[C@@H](c3ccccc3)N2[C@H]1Br</smiles>

138a-c, $n=1,2,3$

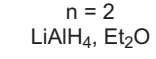<smiles>Oc1ccc2ccccc2c1[C@@H](c1ccccc1)N1CCCC1</smiles>

139a-c, $n=1,2,3$

$\mathrm{Ar}=\mathrm{Ph}, 4-\mathrm{Me}^{-} \mathrm{C}_{6} \mathrm{H}_{4}$, 4-Cl- $\mathrm{C}_{6} \mathrm{H}_{4}, 4-\mathrm{Ph}^{-} \mathrm{C}_{6} \mathrm{H}_{4}, 1-\mathrm{Nph}$<smiles>Oc1ccc2ccccc2c1[C@@H](c1ccccc1)N1CCCC[C@@H]1Br</smiles>

141
$\mathrm{LiAlH}_{4}, \mathrm{Et}_{2} \mathrm{O}$<smiles>Br[C@H]1CCC[C@@H]2Oc3ccc4ccccc4c3[C@@H](c3ccccc3)N12</smiles>

140

Scheme 40. Transformations of (S)-3a into non-racemic aminonaphthols.

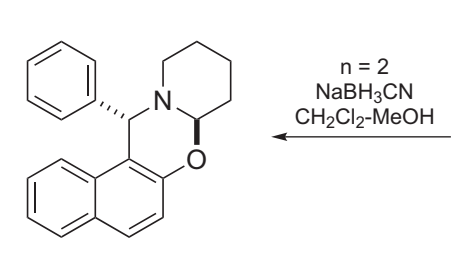<smiles>CC1CCC2C[C@@H](Br)N1[C@H](c1ccccc1)c1c(ccc3ccccc13)O2</smiles>

138a-c, $n=1,2,3$

$$
\mathrm{n}=2
$$$$
\mathrm{MeMgCl} \text {, THF }
$$

$\mathrm{R}^{1} \mathrm{MgBr} \mathrm{Et}_{2} \mathrm{O}$<smiles>[R1]C1CCCCN1[C@@H](c1ccccc1)c1c(O)ccc2ccccc12</smiles>

143

hydrogenol<smiles>[R]C1CCCCN1</smiles>

144

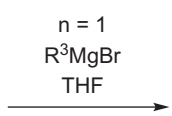<smiles>[R]C1CC[C@@H]2Oc3ccc4ccccc4c3[C@@H](c3ccccc3)N12</smiles>

148<smiles>[R16]CCCCOCC</smiles><smiles>[R3]C1CCC([R4])N1[C@H](c1ccccc1)c1c(O)ccc2ccccc12</smiles>

149<smiles>CC(C)C1(C(C)C)CCC[C@@H](I)N1[C@H](c1ccccc1)c1c(O)ccc2ccccc12</smiles>

146, $n=2,8,10,12,14$

$\mathrm{Pd} / \mathrm{C}, \mathrm{H}_{2}$<smiles>CCCC1CCC[C@@H](C)N1</smiles>

$\mathrm{HCl}$

147, $n=2,8,10,12,14$

Scheme 41. Syntheses of enantiopure piperidines and pyrrolidines.

Chloro derivatives proved to be more active than bromo derivatives. Substituents on C-4 of the thiazole or oxazole nucleus contributed to the fungicidal activity in the following sequence: chlorophenyl $\geq-$ bromophenyl $>$ naphthyl $>$ nitrophenyl. The pathogenic bacteria were equally sensitive to the compounds at $100 \mathrm{ppm}$. It was also observed that thiazolyl-substituted compounds were generally slightly more active than the oxazolyl-substituted derivatives. ${ }^{12}$

de Witte et al. evaluated the in vitro and in vivo P-glycoprotein (P-gp)-modulating activities of the products of some substituted analogues of 3a and tylosine by using human MDR1 genetransfected and parental L5178 mouse lymphoma cell lines. The most promising compound was $N$-tylosyl-1- $\alpha$-amino-(3bromophenyl)methyl-2-naphthol. ${ }^{113}$

A series of racemic 1-((4-(2-(dialkylamino)ethoxy)phenyl)-(2hydroxynaphthalen-1-yl)methyl)piperidin-4-ols (15a-f) were evaluated against oestrogen-responsive human MCF-7 breast cancer cells. The moderate activities of $\mathbf{1 5 a}-\mathbf{f}$ were explained by the molecular bulk resulting in an inadequate fit at the receptor, and 


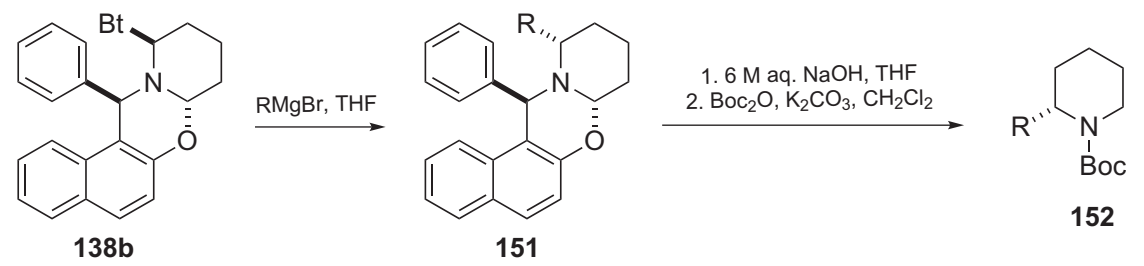

Scheme 42. Synthesis of non-racemic 2-substituted piperidines $\mathbf{1 5 2}$.

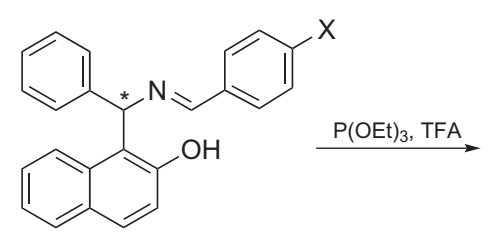

153a-c<smiles>[X]c1ccc(C(N=C(c2ccccc2)c2c(O)ccc3ccccc23)P(=O)(OCC)OCC)cc1</smiles>

$154 a-c$<smiles>[X]c1ccc(C(N)=[PH](=O)(O)O)cc1</smiles>

$155 a-c$

$\mathrm{X}=\mathrm{H}, \mathrm{Me}, \mathrm{Br}$

Scheme 43. Syntheses of enantiopure $\alpha$-aminophosphonic acid derivatives.<smiles>[X]c1ccc(C(N[C@@H](C)c2ccccc2)c2c(O)ccc3ccccc23)cc1</smiles>

156<smiles>[X]c1ccc(C(c2c(O)ccc3ccccc23)N(C(=O)O)[C@@H](C)c2ccccc2)cc1</smiles>

157<smiles>[X]c1ccc([C@H](c2c(O)ccc3ccccc23)N(C(C)c2ccccc2)P(Oc2ccccc2)Oc2ccc3ccccc3c2-c2c(O)ccc3ccccc23)cc1</smiles>

160
$n$-BuLi, $-78{ }^{\circ} \mathrm{C}$, then $\mathrm{PCl}_{3},-78$ to $0{ }^{\circ} \mathrm{C}$

(R)-BINOL or (S)-BINOL, $\mathrm{Et}_{3} \mathrm{~N}, 0^{\circ} \mathrm{C}$ to $\mathrm{rt}$

acetone, reflux<smiles>[R]Oc1ccc2ccccc2c1C(C)CC(C)=O</smiles>

158

$\mathrm{Pd} / \mathrm{C}, \mathrm{H}_{2}$<smiles>[R]Oc1ccc2ccccc2c1C(N[C@@H](C)c1ccccc1)c1ccc([X])cc1</smiles>

159

$X=\mathrm{H}, \mathrm{Me}, \mathrm{Cl}$

$\mathrm{R}=\mathrm{Me}, \mathrm{Et}$

Scheme 44. Syntheses of chiral phosphoramidate ligands $\mathbf{1 6 0}$

the molecular motif was modified by removal of the piperidinol moiety to furnish achiral 1-(4-(2-(dialkylamino)ethoxy)benzyl) naphthalen-2-ols. This new series of compounds displayed significantly enhanced cytotoxicity against MCF-7 cells. ${ }^{29}$

\section{Conclusions and outlook}

The high number of publications that have recently appeared on the syntheses and applications of the mMR is a clear indication that this mode of synthesis has again become a hot topic in organic chemistry. It is also clear that the most important area of application of the non-racemic aminonaphthols prepared in this manner is their use in asymmetric transformations, either as chiral ligands or as chiral auxiliaries. It should be mentioned that the relatively high molecular weights of this type of non-racemic molecules is their only disadvantage of their use in organocatalytic reactions. The functional groups in these Mannich products offer many ringclosure possibilities. Some of these products or the starting bifunctional compounds possess biophore units with promising biological activity. Thanks to the immense number of possibilities for three-component mMR through the use of different amines and/or aldehydes, the continued evolution of the literature on these reactions appears guaranteed, while the synthetic behaviour of 2naphthol will find interest in the context of other electron-rich aromatic compounds, such as quinolinols, isoquinolinols or phenols.

\section{Acknowledgements}

The authors thank the Hungarian Research Foundation (OTKA No. K-75433) and TÁMOP-4.2.2/A-11/1/KONV-2012-0052 for 
financial support. I.S. acknowledges the award of a János Bolyai Fellowship.

\section{References and notes}

1. Encyclopedia of Reagents for Organic Synthesis; Paqett, L. O., Ed.; Wiley: UK, 1995; Vol. 4, p 2582.

2. Tramontini, M.; Angiolini, L. Tetrahedron 1990, 46, 1791.

3. Betti, M. Gazz. Chim. Ital. 1901, 31,170.

4. Betti, M. Gazz. Chim. Ital. 1901, 31, 191.

5. Betti, M. Organic Syntheses; John Wiley \& Sons: New York, 1941; Collect. Vol. 1; p 381.

6. Szatmári, I.; Fülöp, F. Curr. Org. Synth. 2004, 1, 155

7. Cardellicchio, C.; Capozzi, M. A. M.; Naso, F. Tetrahedron: Asymmetry 2010, 21, 507.

8. Shaterian, H. R.; Yarahmadi, H. Tetrahedron Lett. 2008, 49, 1297.

9. Shakibaei, G. I.; Khavasi, H. R.; Mirzaei, P.; Bazgir, A. J. Heterocycl. Chem. 2008, $45,1481$.

10. Nandi, G. C.; Samai, S.; Kumar, R.; Singh, M. S. Tetrahedron Lett. 2009, 50, 7220

11. Phillips, J. P.; Keown, R. W.; Fernando, Q. J. Org. Chem. 1954, 19, 907.

12. Nath, J. P.; Dash, M.; Satrusallya, S. C.; Mahapatra, G. N. Indian J. Chem. 1981, 7, 606.

13. Möhrle, H.; Miller, C.; Wendisch, D. Chem. Ber. 1974, 107, 2675

14. Lu, Y.; Nikolovska-Coleska, Z.; Fang, X.; Gao, W.; Shangary, S.; Qiu, S.; Qin, D.; Wang, S. J. Med. Chem. 2006, 49, 3759.

15. McLean, L. R.; Zhang, Y.; Li, H.; Li, Z.; Lukasczyk, U.; Choi, Y. M.; Han, Z.; Prisco, J.; Fordham, J.; Tsay, J. T.; Reiling, S.; Vaz, R. J.; Li, Y. Bioorg. Med. Chem. Lett. 2009, 19, 6717.

16. Cournia, Z.; Leng, L.; Gandavadi, S.; Du, X.; Bucala, R.; Jorgensen, W. L. J. Med. Chem. 2009, 52, 416.

17. Szatmári, I.; Fülöp, F. Synthesis 2009, 775.

18. Heydenreich, M.; Koch, A.; Klod, S.; Szatmári, I.; Fülöp, F.; Kleinpeter, E. Tetrahedron 2006, 62, 11081.

19. Turgut, Z.; Pelit, E.; Köycü, A. Molecules 2007, 12, 345.

20. Tóth, D.; Szatmári, I.; Heydenreich, M.; Koch, A.; Kleinpeter, E.; Fülöp, F. J. Mol. Struct. 2009, 929, 58.

21. Tóth, D.; Szatmári, I.; Fülöp, F. Eur. J. Org. Chem. 2006, 4664.

22. Alfonsov, V. A.; Metlushka, K. E.; McKenna, C. E.; Kashemirov, B. A.; Kataeva O. N.; Zheltukhin, V. F.; Sadkova, D. N.; Dobrynin, A. B. Synlett 2007, 488.

23. Mayekar, A. N.; Yathirajan, H. S.; Narayana, B.; Sarojini, B. K.; Kumari, N. S. Harrison, W. T. A. Int. J. Chem. 2011, 3, 74.

24. Foroughifar, N.; Mobinikhaledi, A.; Moghanian, H.Synth. Commun. 2010, 40,1812.

25. Jha, A.; Paul, N. K.; Trikha, S.; Cameron, T. S. Can. J. Chem. 2006, 84, 843.

26. Kumar, A.; Gupta, M. K.; Kumar, M. Tetrahedron Lett. 2010, 51, 1582.

27. Karmakar, B.; Banerji, J. Tetrahedron Lett. 2010, 52, 4957.

28. Mukherjee, C.; MacLean, E. D.; Cameron, T. S.; Jha, A. J. Mol. Catal. B 2010, 62, 46

29. Yadav, Y.; MacLean, E. D.; Bhattacharyya, A.; Parmar, V. S.; Balzarini, J.; Barden, C. J.; Too, C. K. L.; Jha, A. Eur. J. Med. Chem. 2011, 46, 3858.

30. Mathew, B. P.; Nath, M. J. Heterocycl. Chem. 2009, 46, 1003.

31. Sadaphal, S. A.; Sonar, S. S.; Shingate, B. B.; Shingare, M. S. Green Chem. Lett. Rev. 2010, 3, 213.

32. Ji, J. X.; Wu, J.; Au-Yeung, T. T. L.; Yip, C. W.; Haynes, R. K.; Chan, A. S. C. J. Org. Chem. 2005, 70, 1093

33. Szatmári, I.; Sillanpää; Fülöp, F. Tetrahedron: Asymmetry 2008, 19, 612.

34. Wei, H.; Yin, L.; Luo, H.; Li, X.; Chan, A. S. C. Chirality 2011, 23, 222.

35. Cimarelli, C.; Fratoni, D.; Mazzanti, A.; Palmieri, G. Tetrahedron: Asymmetry 2011, 22, 591.

36. Cappannini, L.; Cimarelli, C.; Giuli, S.; Palmieri, G.; Petrini, M. Tetrahedron: Asymmetry 2007, 18, 1022.

37. Rondot, C.; Zhu, J. Org. Lett. 2005, 7, 1641.

38. Ghandi, M.; Olyaei, A.; Raoufmoghaddam, S. Synth. Commun. 2008, 38, 4125

39. Ghandi, M.; Olyaei, A.; Raoufmoghaddam, S. J. Heterocycl. Chem. 2009, 46, 914

40. Olyaei, A.; Raoufmoghaddam, S.; Sadeghpour, M.; Ebadzadeh, B. Chin. J. Chem. 2010, 28, 825 .

41. Shaabani, A.: Rahmati, A.; Farhangi, E. Tetrahedron Lett. 2007, 48, 7291.

42. Xiong, R. G. Lett. Org. Chem. 2008, 5, 265.

43. Sun, Y.; Li, Z. M.; Shen, X. M.; Ma, F. N.; Zhang, C. Chin. Chem. Lett. 2005, 16, 879

44. Li, Z. M.; Sun, Y.; Shen, X.-M.; Ai, L.; Zhang, C. Chin. J. Org. Chem. 2006, 26, 465.

45. Ma, F.; Ai, L.; Shen, X.; Zhang, C. Org. Lett. 2007, 9, 125.

46. Huang, P.-J.; Youssef, D.; Cameron, S.; Jha, A. ARKIVOC 2008, xvi, 165.

47. Toyama, M.; Otomasu, H. Chem. Pharm. Bull. 1985, 33, 5543.

48. Möhrle, H.; Miller, C. Monatsh. Chem. 1974, 105, 1151

49. Saidi, M.; Azizi, N.; Naimi-Jamal, R. Tetrahedron Lett. 2001, 42, 8111.

50. Cimarelli, C.; Mazzanti, A.; Palmieri, G.; Volpini, E. J. Org. Chem. 2001, 66, 4759

51. Pirrone, P. Gazz. Chim. Ital. 1940, 70, 520

52. Pirrone, P. Gazz. Chim. Ital. 1941, 71, 320.

53. Phillips, J. P.; Keown, R.; Frenando, Q. J. Am. Chem. Soc. 1953, 75, 4306.

54. Phillips, J. P.; Duckwall, A. L. J. Am. Chem. Soc. 1955, 77, 5504.

55. Sen, A. B.; Saxena, M. S. J. Indian Chem. Soc. 1956, 33, 62.

56. Phillips, J. P.; Barrall, E. M. J. Org. Chem. 1956, 21, 692.
57. Sen, A. B.; Saxena, M. S.; Mehrotra, S. J. Indian Chem. Soc. 1960, 37, 640. 58. Miyano, S.; Abe, N.; Abe, A.; Hamachi, K. Chem. Pharm. Bull. 1971, 19, 1131 59. Acharya, J. N.; Thaker, K. A. J. Indian Chem. Soc. 1976, 53, 172.

60. Wagner, H.; Woerhammer, R.; Wolff, P. Biochem. Z. 1961, 334, 175.

61. Chaturvedi, K. K.; Goyal, M. J. Indian Chem. Soc. 1984, 61, 175.

62. Niu, L. F.; Xin, Y. C.; Wang, R. L.; Jiang, F.; Xu, P. F.; Hui, X. P. Synlett 2010, 765.

63. Chauhan, P.; Chimni, S. S. Eur. J. Org. Chem. 2011, 1636.

64. Szatmári, I.; Lázár, L.; Fülöp, F. Tetrahedron Lett. 2006, 47, 3881.

65. MacLeod, P. D.; Li, Z.; Feng, J.; Li, C. J. Tetrahedron Lett. 2006, 47, 6791.

66. MacLeod, P. D.; Li, Z.; Li, C. J. Tetrahedron 2010, 66, 1045.

67. MacLeod, P. D.; Reckling, A.; Li, C. J. Heterocycles 2010, 80, 1319

68. Szatmári, I.; Fülöp, F. Synthesis 2011, 745.

69. Cimarelli, C.; Fratoni, D.; Mazzanti, A.; Palmieri, G. Eur. J. Org. Chem. 2011 2094.

70. Lázár, L.; Fülöp, F. Eur. J. Org. Chem. 2003, 3025.

71. Szatmári, I.; Martinek, T. A.; Lázár, L.; Fülöp, F. Tetrahedron 2003, 59, 2877.

72. Szatmári, I.; Martinek, T. A.; Lázár, L.; Koch, A.; Kleinpeter, E.; Neuvonen, K.; Fülöp, F. J. Org. Chem. 2004, 69, 3645.

73. Szatmári, I.; Martinek, T. A.; Lázár, L.; Fülöp, F. Eur. J. Org. Chem. 2004, 2231

74. Szatmári, I.; Tóth, D.; Koch, A.; Heydenreich, M.; Kleinpeter, E.; Fülöp, F. Eur. I. Org. Chem. 2006, 4670 .

75. Liu, B.; Su, D.; Cheng, G.; Liu, H.; Wang, X.; Hu, Y. Synthesis 2009, 3227.

76. Azizian, J.; Yadollahzadeh, K.; Delbari, A. S.; Ghanbari, M. M. Monatsh. Chem. 2012, 143, 1417.

77. Damodiran, M.; Selvam, N. P.; Perumal, P. T. Tetrahedron Lett. 2009, 50, 5474.

78. Shi, D.; Rong, S.; Dou, G.; Wang, M. J. Comb. Chem. 2009, 12, 25.

79. Csütörtöki, R.; Szatmári, I.; Koch, A.; Heydenreich, M.; Kleinpeter, E.; Fülöp, F. Tetrahedron 2012, 68, 4600.

80. Kanemitsu, T.; Asajima, Y.; Shibata, T.; Miyazaki, M.; Nagata, K.; Itoh, T. Heterocycles 2011, 83, 2525.

81. Chopde, H. N.; Meshram, J. S.; Pagadala, R.; Mungole, A. J. Int. J. ChemTech Res. 2010, 2, 1823.

82. Heydenreich, M.; Koch, A.; Szatmári, I.; Fülöp, F.; Kleinpeter, E. Tetrahedron 2008, 64, 7378.

83. Kleinpeter, E.; Szatmári, I.; Lázár, L.; Koch, A.; Heydenreich, M.; Fülöp, F. Tetrahedron 2009, 65, 8021.

84. Szatmári, I.; Fülöp, F. Tetrahedron Lett. 2011, 52, 4440.

85. Durmaz, M.; Yilmaz, M.; Sirit, A. Org. Biomol. Chem. 2011, 9, 571.

86. Dahmen, S.; Lormann, M. Org. Lett. 2005, 7, 4597.

87. Dong, Y.; Li, R.; Lu, J.; Xu, X.; Wang, X.; Hu, Y. J. Org. Chem. 2005, 70, 8617.

88. Kaiser, P. F.; White, J. M.; Hutton, C. A. J. Am. Chem. Soc. 2008, 130, 16450.

89. Xu, X.; Lu, J.; Li, R.; Ge, Z.; Dong, Y.; Hu, Y. Synlett 2004, 122.

90. Wang, X.; Dong, Y.; Sun, J.; Xu, X.; Li, R.; Hu, Y. J. Org. Chem. 2005, 70, 1897.

91. Cheng, G.; Wang, X.; Zhu, R.; Chao, C.; Xu, J.; Hu, Y. J. Org. Chem. 2011, 76, 2694

92. Liu, H.; Su, D.; Cheng, G.; Xu, J.; Wang, X; Hu, Y. Org. Biomol. Chem. 2010, 1899

93. Cheng, G.; Wang, X.; Su, D.; Liu, H.; Liu, F.; Hu, Y. J. Org. Chem. 2010, 75, 1911.

94. Metlushka, K. E.; Kashemirov, B. A.; Zheltukhin, V. F.; Sadkova, D. N.; Büchner, B.; Hess, C.; Kataeva, O. N.; McKenna, C. E.; Alfonsov, V. A. Chem.-Eur. J. 2009, 15,6718 .

95. Metlushka, K. E.; Sadkova, D. N.; Shaimardanova, L. N.; Kataeva, O. N.; Alfonsov, V. A. Phosphorus, Sulfur and Silicon 2011, 186, 712.

96. Li, X.: Song, J.: Xu, D; Kong, L. Synthesis 2008, 925.

97. Chaudhary, A. R.; Bedekar, A. V. Synth. Commun. 2012, 42, 1778.

98. Lämmermann, A.; Szatmári, I.; Fülöp, F.; Kleinpeter, E. J. Phys. Chem. A 2009, $113,6197$.

99. Sztojkov-Ivanov, A.; Szatmári, I.; Péter, A.; Fülöp, F. J. Sep. Sci. 2005, 28, 2505.

100. Berkecz, R.; Ilisz, I.; Sztojkov-Ivanov, A.; Szatmári, I.; Fülöp, F.; Armstrong, D. W.; Péter, A. Chromatographia 2007, 65, 337.

101. Sztojkov-Ivanov, A.; Tóth, D.; Szatmári, I.; Fülöp, F.; Péter, A. Chirality 2007, 19, 374.

102. Ilisz, I.; Pataj, Z.; Berkecz, R.; Szatmári, I.; Fülöp, F.; Péter, A. Chromatographia 2009, 70, 723 .

103. Ilisz, I.; Iványi, R.; Pataj, Z.; Kupai, J.; Huszthy, P.; Szatmári, I.; Fülöp, F.; Péter, A. Chromatographia 2010, 71, S115.

104. Aranyi, A.; Ilisz, I.; Pataj, Z.; Szatmári, I.; Fülöp, F.; Armstrong, D. W.; Péter, A. Chirality 2011, 23, 549.

105. Ilisz, I.; Pataj, Z.; Berkecz, R.; Szatmári, I.; Fülöp, F.; Péter, A. J. Chromatogr., A 2010, 1217, 2980.

106. Aranyi, A.; Ilisz, I.; Pataj, Z.; Szatmári, I.; Fülöp, F.; Péter, A. J. Chromatogr., A 2011, 1218, 4869 .

107. Martiskainen, O.; Fülöp, F.; Szatmári, I.; Pihlaja, K. ARKIVOC 2009, iii, 115.

108. Patel, M.; McHugh, R. J.; Beverly, J. Bioorg. Med. Chem. Lett. 1999, 9, 3221.

109. Waxman, L.; Darke, P. L. Antiviral Chem. Chemother. 2000, 11, 1.

110. Girgis, A. S. Pharmazie 2000, 426.

111. Latif, N.; Mishriky, N.; Assad, F. M. Aust. J. Chem. 1982, 35, 1037.

112. Patel, M.; Ko, S. S.; McHugh, R. J., Jr.; Markwalder, J. A.; Srivastave, A. S.; Cordova, B. C.; Klabe, R. M.; Ericson-Viitanem, S.; Trainor, G. L.; Seitz, S. P. Bioorg. Med. Chem. Lett. 1999, 9, 2805.

113. Gyémánt, N.; Engi, H.; Schelz, Z.; Szatmári, I.; Tóth, D.; Fülöp, F.; Molnár, J.; de Witte, P. Br. J. Cancer 2010, 103, 178. 


\section{Biographical sketch}

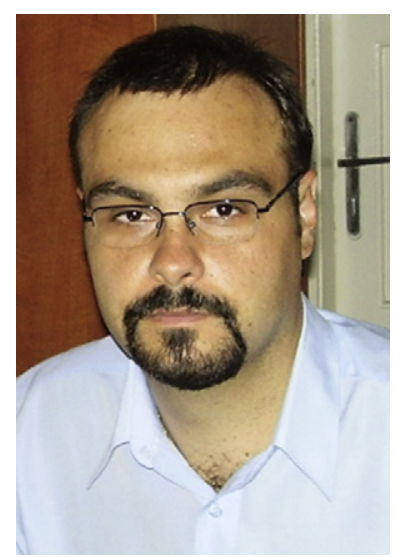

István Szatmári was born in Satu Mare, Romania, in 1976. He received his BSc in Chemistry and Physics in 1998 and his PhD in 2004 from the University of Szeged, Hungary, under the supervision of Professor Ferenc Fülöp. Since 2006, he has been a research assistant at the Institute of Pharmaceutical Chemistry, University of Szeged. His research interests include the synthesis of heterocyclic compounds, including isoquinolines and saturated 1,3-heterocycles, and the ring-chain tautomerism of 1,3heterocycles prepared via modified Mannich reactions.

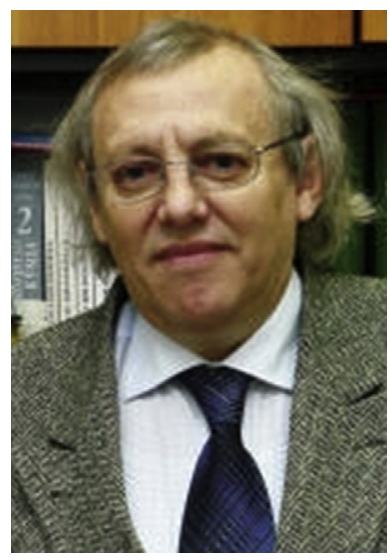

Ferenc Fülöp was born in Szank, Hungary, in 1952. He received his MSc in Chemistry in 1975 and his PhD in 1979, from József Attila University, Szeged, Hungary, under the supervision of Professor Gábor Bernáth. In 1991, he was appointed as a full professor at the Institute of Pharmaceutical Chemistry, University of Szeged and, since 1998, he has been head of the Institute. He has a wide range of research interests in heterocyclic chemistry, including isoquinolines, saturated 1,3-heterocycles, and the ring-chain tautomerism of 1,3-heterocycles. His recent activities have focused on the use of amino alcohols and $\beta$-amino acids in enzymatic transformations, asymmetric syntheses, foldamer construction and combinatorial chemistry, with a view to the development of pharmacologically active compounds. From 2009 he has chaired a European Cost action entitled Functional peptidomimetic foldamers: from unnatural amino acids to selfassembling nanomaterials. 